\title{
The Biosynthesis, Signaling, and Neurological Functions of Bile Acids
}

\author{
Yoshimitsu Kiriyama ${ }^{(D)}$ and Hiromi Nochi *(D) \\ Kagawa School of Pharmaceutical Sciences, Tokushima Bunri University, Shido 1314-1, Kagawa, \\ Sanuki 769-2193, Japan; kiriyamay@kph.bunri-u.ac.jp \\ * Correspondence: nochi@kph.bunri-u.ac.jp; Tel.: +81-87-899-7100; Fax: +81-87-894-0181
}

Received: 27 May 2019; Accepted: 14 June 2019; Published: 15 June 2019

\begin{abstract}
Bile acids (BA) are amphipathic steroid acids synthesized from cholesterol in the liver. They act as detergents to expedite the digestion and absorption of dietary lipids and lipophilic vitamins. $\mathrm{BA}$ are also considered to be signaling molecules, being ligands of nuclear and cell-surface receptors, including farnesoid $\mathrm{X}$ receptor and Takeda G-protein receptor 5. Moreover, BA also activate ion channels, including the bile acid-sensitive ion channel and epithelial $\mathrm{Na}^{+}$channel. BA regulate glucose and lipid metabolism by activating these receptors in peripheral tissues, such as the liver and brown and white adipose tissue. Recently, 20 different BA have been identified in the central nervous system. Furthermore, BA affect the function of neurotransmitter receptors, such as the muscarinic acetylcholine receptor and $\gamma$-aminobutyric acid receptor. BA are also known to be protective against neurodegeneration. Here, we review recent findings regarding the biosynthesis, signaling, and neurological functions of BA.
\end{abstract}

Keywords: bile acids; FXR; TGR5; SHP; Alzheimer's disease; Parkinson's disease; Huntington's disease; ALS

\section{Introduction}

Bile acids (BA) are synthesized from cholesterol in the liver and are a significant component of bile. They are stored in the gallbladder and released into the small intestine after a meal. BA are amphipathic steroid acids and are known as indispensable detergents, expediting the digestion and absorption of dietary lipids and lipophilic vitamins by forming micelles in the small intestine. Recently, they have also been considered to be signaling molecules. They are now recognized as ligands of farnesoid X receptor (FXR), a nuclear hormone receptor, and Takeda G-protein receptor 5 (TGR5), a G-protein-coupled receptor (GPCR) that is also known as G protein-coupled bile acid receptor 1 (GPBAR1) [1].

Bile salt composition of a variety of vertebrate species is validated. Bile salts include $C_{27}$ bile alcohols, $\mathrm{C}_{27}$ bile acids, and $\mathrm{C}_{24}$ bile acids. $\mathrm{C}_{24}$ bile acids exist in all vertebrates, although $\mathrm{C}_{27}$ bile alcohols and $\mathrm{C}_{27}$ bile acids exist in fish, amphibians, reptiles, and birds [2]. $5 \alpha-\mathrm{C}_{27}$ bile alcohol sulfates are considered as the first ancestral bile salts. $5 \alpha$-cyprinol sulfate is $5 \alpha-C_{27}$ bile alcohol sulfate and activates FXR from the frog and the zebrafish, but not from the human and the mouse. In contrast, taurochenodeoxycholic acid (TCDCA) and lithocholic acid (LCA) activate FXR from the human and the mouse, but not from the frog and the zebrafish. Thus, the structure of FXR may be changed to adapt to bind species-specific bile salts [3].

BA regulate glucose and lipid metabolism by activating these receptors in various peripheral tissues, including the liver, brown and white adipose tissue, skeletal muscle, and the pancreas [4]. In addition, a recent study has shown that 20 different kinds of BA can be found in the central nervous system (CNS) and the presence of two primary bile acids, chenodeoxycholic acid (CDCA) and cholic 
acid (CA), in the brain is essential [5,6]. In this review, we focus on recent advances in the understanding of the biosynthesis, signaling, and neurological functions of BA.

\section{Synthesis of BA}

BA are predominantly produced in the liver, via two biosynthetic pathways: The classical (or neutral) pathway and the alternative (or acidic) pathway [7] (Figure 1). The synthesis of BA from cholesterol involves at least 16 enzymes [8]. The classical pathway is initiated by cytochrome P450 7A1 (CYP7A1), also known as cholesterol $7 \alpha$ hydroxylase. Cholesterol is converted to $7 \alpha$-hydroxycholesterol by CYP7A1, which is the rate-limiting enzyme in this pathway. $7 \alpha$-hydroxycholesterol is then converted to $7 \alpha$-Hydroxy-4-cholesten-3-one. Cytochrome P450 8B1 (CYP8B1), also known as sterol $12 \alpha$-hydroxylase, is responsible for the production of CA from $7 \alpha$-hydroxy-4-cholesten-3-one, but $7 \alpha$-hydroxy-4-cholesten-3-one is also converted to CDCA by cytochrome P450 27A1 (CYP27A1), also known as sterol 27-hydroxylase. The alternative pathway begins with the conversion of cholesterol to (25R)-26-hydroxycholesterol [9] by CYP27A1. Cytochrome P450 7B1 (CYP7B1), also known as oxysterol 7- $\alpha$-hydroxylase, leads (25R)-26-hydroxycholesterol to CDCA. CDCA is converted to $\alpha$-muricholic acid (MCA), and $\beta$-MCA. These BA are then conjugated with glycine or taurine. BA synthesized in the liver are referred to as "primary BA" [10-12]. Primary BA in rodents are also conjugated with taurine in the liver [13]. Bile salt export pump (BSEP) and multidrug resistance-associated protein 2 (MRP2) are the transporters that mediate the secretion of BA from hepatocytes into hepatic bile canaliculi (Figure 2). BSEP is the main transporter of BA, whereas MRP2 principally transports BA glucuronides and sulfates [1,14].
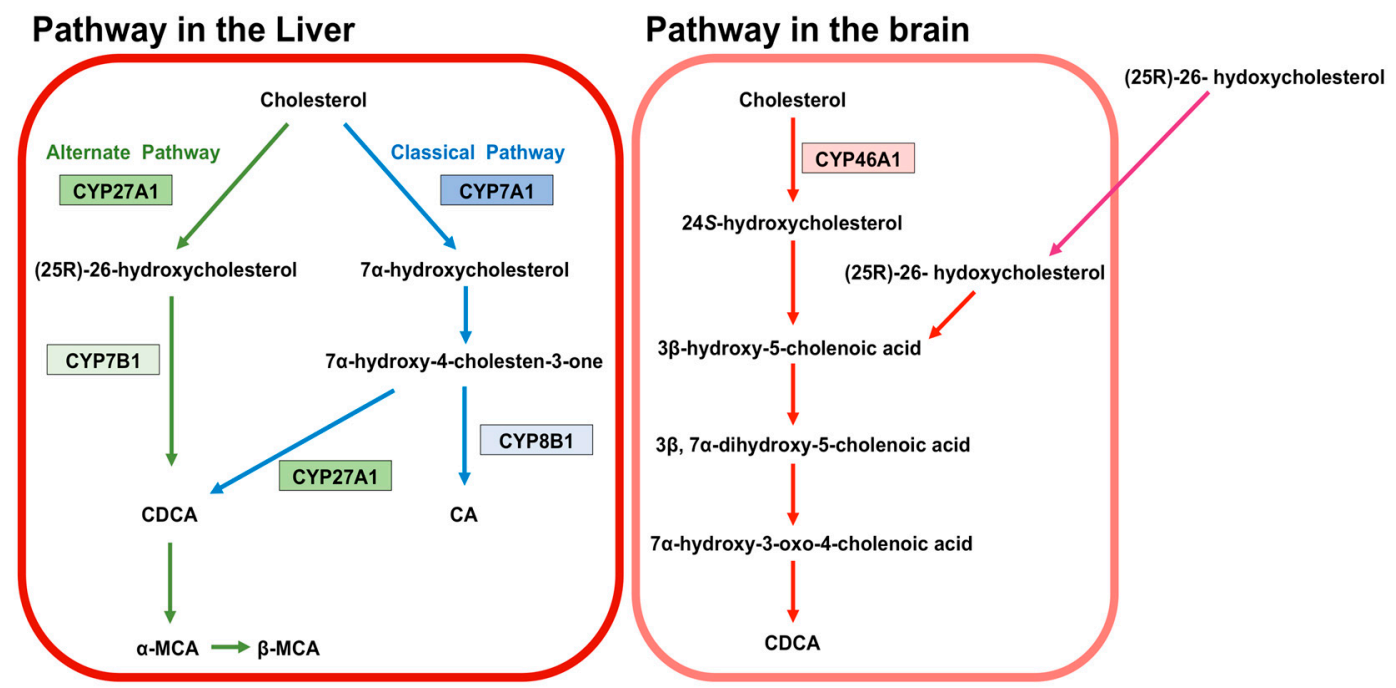

Figure 1. Synthesis of bile acids (BA). The classical pathway is initiated by cytochrome P450 7A1 (CYP7A1). CYP7A1 converts cholesterol to $7 \alpha$-hydroxycholesterol. $7 \alpha$-hydroxycholesterol is then converted to $7 \alpha$-hydroxy-4-cholesten-3-one. Cytochrome P450 8B1 (CYP8B1) leads the production of $\mathrm{CA}$ from $7 \alpha$-hydroxy-4-cholesten-3-one. $7 \alpha$-hydroxy-4-cholesten-3-one is also converted to CDCA by cytochrome P450 27A1 (CYP27A1). The alternative pathway begins with converting cholesterol to (25R)-26-hydroxycholesterol by CYP27A1. Cytochrome P450 7B1 (CYP7B1) leads (25R)-26-hydroxycholesterol to CDCA. CDCA is converted to $\alpha$-muricholic acid (MCA), and $\beta$-MCA. These $\mathrm{BA}$ are then conjugated with glycine or taurine. BA in rodents are also conjugated with taurine in the liver. BA synthesized in the liver are called primary BA. In the brain, 24S-hydroxycholesterol is converted from cholesterol by cytochrome P450 46A1 (CYP46A1). 24S-hydroxycholesterol is a precursor of $3 \beta$-hydroxy-5-cholenoic acid, which can be converted to CDCA through the intermediates ( $3 \beta, 7 \alpha$-dihydroxy-5-cholenoic acid and $7 \alpha$-hydroxy-3-oxo-4-cholenoic acid). A large amount of (25R)-26-hydoxycholesterol incorporates to brain from circulation, and (25R)-26-hydoxycholesterol can also be converted to $3 \beta$-hydroxy-5-cholenoic acid. 


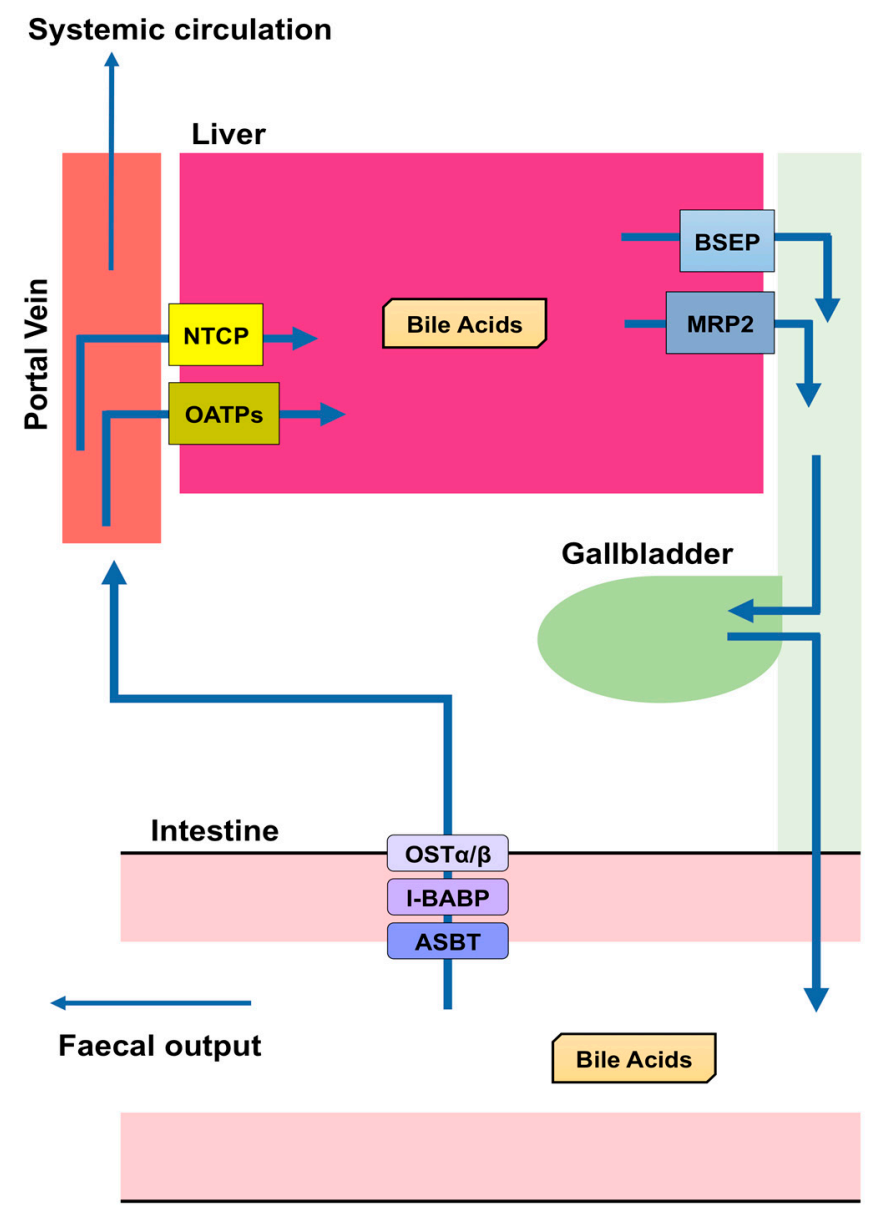

Figure 2. Enterohepatic circulation. Bile salt export pump (BSEP) and multidrug resistance-associated protein 2 (MRP2) are transporters mediating the secretion of bile acids (BA) from hepatocytes to the bile canaliculus in the liver. BA are stored in the gallbladder and secreted into the small intestine after a meal. Most BA (approximately 95\%) are reabsorbed, whereas the remainder is excreted with feces. Apical sodium dependent bile acid transporter (ASBT) in the apical brush border of enterocytes takes BA into enterocytes. Ileal bile acid-binding protein (I-BABP) is related to the intracellular transport in enterocytes. The passage of BA through the basolateral membrane of enterocytes into the portal blood occurs through organic solute transporter (OST) $\alpha$ and $\beta$. BA released into the blood from the small intestine are transported into the liver by $\mathrm{Na}^{+}$-taurocholate co-transporting polypeptide (NTCP) or organic anion-transporting polypeptides (OATPs). These BA are then reconjugated and secreted with newly produced BA. This recycling system is termed enterohepatic circulation.

After primary BA are transported to and stored in the gallbladder, they are secreted into the small intestine, where the intestinal microbiota converts them into secondary BA. Conjugated primary BA are deconjugated by bacterial bile salt hydrolase $[15,16]$. In humans, $7 \alpha$-dehydroxylase converts CA and CDCA to deoxycholic acid (DCA) and lithocholic acid (LCA), respectively [1,16]. CDCA is also converted to ursodeoxycholic acid (UDCA) by $7 \alpha$-hydroxysteroid dehydrogenase $(7 \alpha-\mathrm{HSDH})$ and $7 \beta-\mathrm{HSDH}$ [17]. In rodents, $\beta$-MCA is transformed into $\omega-\mathrm{MCA}$, which is then metabolized to hyodeoxycholic acid (HDCA), while $\alpha$-MCA is converted to murideoxycholic acid $[18,19]$.

Most BA molecules (approximately 95\%) are reabsorbed, and the remainders are excreted in the feces [20]. This reabsorption largely takes place in the small intestine, but a small proportion also occurs in the colon. Apical sodium dependent bile acid transporter (ASBT) in the apical brush border of enterocytes transports BA into enterocytes [21-25], and a mutation in this transporter causes primary BA malabsorption [22]. Although diabetes is a multifactorial disease, appropriate glycemic control is crucial for the prevention of diabetic complications [26-29]. Inhibition of the reabsorption 
of BA by an ASBT inhibitor (GSK2330672) or a BA sequestrant (colesevelam or colestimide) causes a reduction in circulating $B A$ concentrations, which leads to improvements in glycemic control and insulin sensitivity in diabetic patients [30,31]. Ileal bile acid-binding protein (I-BABP), also known as fatty acid binding protein 6 , mediates intracellular transport in the enterocyte [21,32], and the transport of BA through the basolateral membrane of enterocytes into the portal circulation is performed by organic solute transporter (OST) $\alpha$ and $\beta$. OST $\alpha$ and OST $\beta$ are localized to the basolateral membranes of the enterocyte [21] and expressed as heterodimers or heteromultimers [33-35]. BA released into the blood from the small intestine are transported to the liver, reconjugated, and secreted with newly synthesized BA. Thus, BA secreted from the liver into the intestine are recycled, and this recycling system is referred to as the "enterohepatic circulation" (Figure 2).

The transport of BA from the portal circulation into hepatocytes is performed by $\mathrm{Na}^{+}$-dependent and $\mathrm{Na}^{+}$-independent pathways. $\mathrm{Na}^{+}$-dependent transport of $\mathrm{BA}$ requires $\mathrm{Na}^{+}$-taurocholate co-transporting polypeptide (NTCP), while $\mathrm{Na}^{+}$-independent transport is executed by organic anion-transporting polypeptides (OATPs). NTCP is localized to the basolateral membrane of hepatocytes and is the main transporter responsible for transporting BA into hepatocytes using a Na ${ }^{+}$-dependent mechanism [36-38]. OATP1B1 and OATP1B3 are members of the OATP family that are expressed in the basolateral membrane of hepatocytes [39]. Oatp1b2 is the rodent ortholog of human OATP1B1/3 [40]. BA conjugated with glycine or taurine are more effectively transported into cells by OATP1B1/3 than unconjugated BA [41]. However, BA in the portal vein are not completely reabsorbed by hepatocytes (Figure 2): The concentration of BA in the portal vein is $10-80 \mu \mathrm{M}$ and that in the systemic circulation of humans and rodents is $\sim 2-10 \mu \mathrm{M}[10]$.

\section{BA in the Brain}

Both conjugated and unconjugated BA can be detected in the brain of humans and rodents [5,6,42]. Twenty BA have been identified in the rat brain, consisting of nine unconjugated BA and eleven conjugated BA [6]. Most of these $20 \mathrm{BA}$ are also found in the blood of rats [43]. CDCA is present in the highest concentration in the rat brain [5]. Although the origin of brain BA remains unclear, they can be synthesized in the brain or transported into the brain from the peripheral circulation by BA transporters and/or diffuse across the blood-brain barrier (BBB). Conjugated BA require transporters to cross the BBB, because they are large and negatively-charged at physiological $\mathrm{pH}[44,45]$, and indeed, transporters for both the uptake and efflux of BA, such as NTCP, OATP1, BSEP, and MRP2, have been identified in the choroid plexus and brain capillaries [46-48]. In addition, BA in the bloodstream can themselves induce permeability of the BBB. The BBB is formed by brain microvascular endothelial cells that are bound to adjacent cells via tight junctions [49]. Occludin is one of the membrane proteins that are responsible for tight junction formation in the BBB [50], and its phosphorylation by BA via ras-related C 3 botulinum toxin substrate 1 (RAC1) increases the permeability of the BBB [51]. In contrast, unconjugated BA, such as CA, CDCA, and DCA, are lipophilic, even though they are ionized [52]. Therefore, unconjugated BA might be able to cross the BBB by passive diffusion, and indeed, there are strong correlations between the concentrations of unconjugated BA (CA, CDCA, and DCA) in the brain and the serum $[53,54]$.

24S-hydroxycholesterol predominantly exists in the brain of humans and rodents and is generated from cholesterol in the brain by cytochrome P450 46A1 (CYP46A1), also known as cholesterol 24-hydroxylase [55-58] (Figure 1). 24S-hydroxycholesterol is a precursor of 3 $\beta$-hydroxy-5-cholenoic acid, which can be converted to CDCA through the intermediates ( $3 \beta, 7 \alpha$-dihydroxy-5-cholenoic acid and $7 \alpha$-hydroxy-3-oxo-4-cholenoic acid) with rat brain extracts, although this CDCA-generating activity is very low [59]. Moreover, a large amount of (25R)-26-hydoxycholesterol incorporates to brain from circulation, and (25R)-26-hydoxycholesterol can also be converted to 3 $\beta$-hydroxy-5-cholenoic acid [60]. Therefore, it is thought that the principal source of BA in the brain is the peripheral circulation. 


\section{Signaling Induced by BA}

FXR and TGR5 are the most studied receptors activated by BA [1], but other nuclear receptors are also activated by $B A$, including pregnane $X$ receptor (PXR), vitamin $D$ receptor (VDR), liver $X$ receptor (LXR), and glucocorticoid receptor (GR) [61,62], and in addition to TGR5, sphingosine-1-phosphate receptor 2 (S1PR2), M2 and M3 muscarinic receptors, and formyl-peptide receptor (FPR) are cell-surface receptors activated by BA. All these receptors are expressed in the brain [63-68]. Furthermore, the bile acid-sensitive ion channel (BASIC), epithelial $\mathrm{Na}^{+}$channel (ENaC), and large-conductance $\mathrm{Ca}^{2+}$-and voltage-activated $\mathrm{K}^{+}(\mathrm{BK})$ channels are ion channels that are activated by BA and are also expressed in the brain [69-73] (Figure 3).

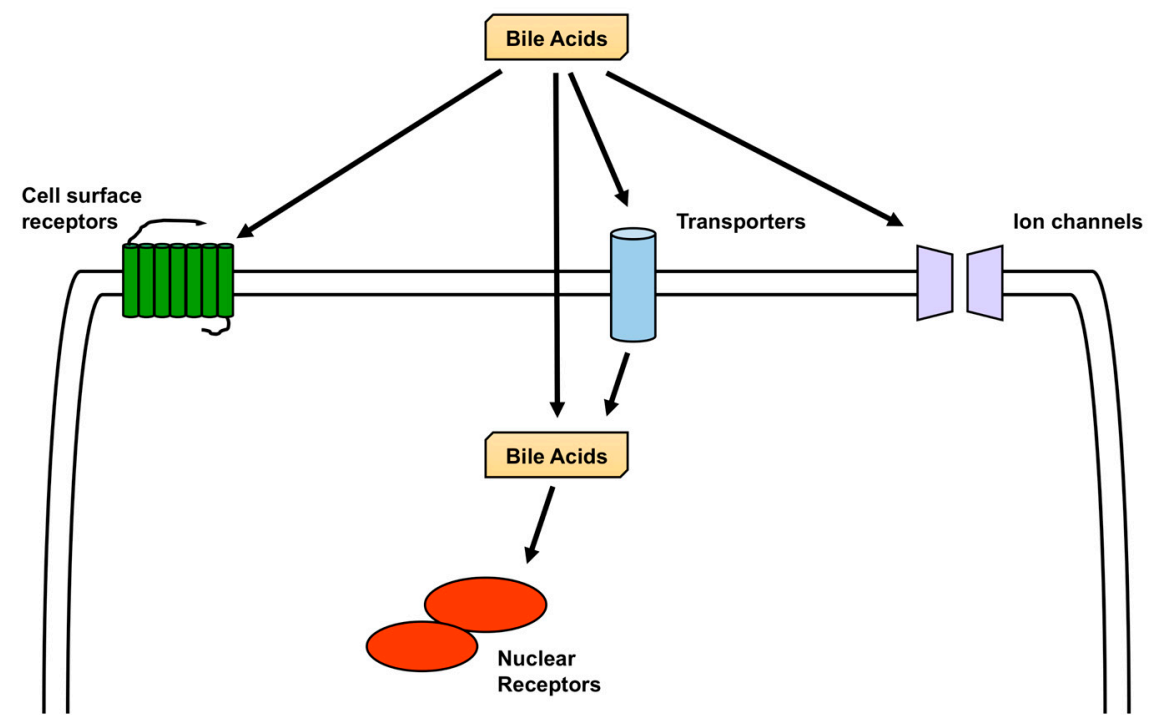

Figure 3. Bile acids (BA) activate receptors and ion channels. Nuclear receptors activated by BA include the farnesoid $X$ receptor (FXR), pregnane $X$ receptor (PXR), vitamin D receptor (VDR), liver $X$ receptor (LXR), and glucocorticoid receptor (GR). Unconjugated BA might be able to cross the plasma membrane, and conjugated BA might cross the plasma membrane using transporters. Cell surface receptors activated by BA are Takeda G-protein receptor 5 (TGR5), sphingosine-1-phosphate receptor 2 (S1PR2), M2 and M3 muscarinic receptors, and formyl-peptide receptor (FPR). Bile acid-sensitive ion channel (BASIC), epithelial $\mathrm{Na}^{+}$channel $(\mathrm{ENaC})$, and large-conductance $\mathrm{Ca}^{2+}$ - and voltage-activated $\mathrm{K}^{+}(\mathrm{BK})$ channels are ion channels that are activated by BA. These receptors and ion channels are expressed in the brain.

\subsection{Activation of Nuclear Receptors by BA}

FXR is a nuclear hormone receptor for which BA are ligands [74-76]. Unconjugated BA, such as CDCA, DCA, and LCA, are high-affinity ligands of FXR [74-76], and CA and conjugated BA can effectively activate FXR in the presence of a BA transporter (NTCP) in the cell [74]. However, taurine- $\beta$-MCA (T $\beta$ MCA), glycine- $\beta$-MCA (G $\beta$ MCA), and DCA act as antagonists at FXR inhibiting FXR signaling [77-79]. FXR monomers and heterodimers with a retinoid-X receptor (RXR) bind to their target sequence on DNA molecules, which is an inverted repeat of AGGTCA separated by one nucleotide (IR1) [80,81]. Moreover, FXR can also bind to IR0, an everted repeat of AGGTCA separated by two or eight nucleotides (ER2 or 8), and a direct repeat of AGGTCA separated by one, four, or five nucleotides (DR1, 4, or 5) [80,82-84]. Comparison of the available DNA binding sites for FXR in the liver and the intestine has shown that they only have $11 \%$ in common [80], suggesting that the pattern of gene expression induced by FXR is tissue-specific, and, thus, that the genes regulated by FXR in the brain might be different from those in peripheral tissues.

PXR, VDR, and LXR also heterodimerize with RXR [85]. PXR is also known as the steroid and xenobiotic receptor (SXR) and is activated by many xenobiotics and endobiotics, but also by 
LCA [86-88]. PXR plays an important role in the regulation of the expression of genes encoding transporters of drugs and enzymes, which are involved in drug metabolism. Drug transporters upregulated by PXR include MRP2 and OATP2, and drug-metabolizing enzymes upregulated by PXR include CYP3A and CYP2B, which metabolize LCA to hyocholic acid and UDCA [84,89-92]. In contrast, CYP7A1 expression is suppressed by PXR, but PXR does not directly bind to the promoter region of the CYP7A1 gene. Instead, PXR suppresses the activation of hepatocyte nuclear factor $4 \alpha$, which binds to the promoter region of the CYP7A1 gene and upregulates its expression $[93,94]$. Thus, PXR regulates genes involved in BA synthesis and metabolism. In addition, PXR expression can be upregulated by FXR [95].

VDR is a nuclear receptor that is crucial for the control of calcium homeostasis. Its main endogenous ligand is 1,25-dihydroxyvitamin D3, but LCA and its metabolite, 3-keto LCA, are also able to activate VDR [96,97]. The activation of VDR leads to the upregulation of CYP family proteins and BA transporters, and in particular, LCA can induce CYP3A and MRP3 expression by acting as a VDR ligand [97-100].

LXR $\alpha$ and $\beta$ control cholesterol homeostasis and are activated by oxysterols, which are endogenously produced cholesterol metabolites, but HDCA is also a weak activator of $\operatorname{LXR} \alpha[101,102]$. $\mathrm{LXR} \alpha$ knockout mice exhibit a reduction in BA pool size and excretion, because LXR $\alpha$ upregulates the expression of CYP7A, which is the key enzyme required for the conversion of cholesterols to BA. In contrast, LXR $\beta$ does not affect the expression of CYP7A [103-105].

GR is activated by glucocorticoids and induces or represses the expression of large numbers of genes, thereby influencing various physiologic functions, including metabolic homeostasis, stress, inflammation, and development [106]. UDCA, taurocholic acid (TCA), and glycochenodeoxycholic acid (GCDA) induce GR activity [107,108], and the activation of GR by UDCA suppresses nuclear factor- $\mathrm{KB}$ activation [108]. Furthermore, the activation of GR by TCA or GCDA reduces the expression of corticotropin-releasing hormone in the hypothalamus [107].

SHP is a nuclear hormone receptor that is induced by the activation of FXR [109] Although it has a ligand-binding domain (LBD), it lacks a DNA binding domain. The endogenous ligand of SHP has yet to be identified. The function of SHP is to repress many nuclear receptors, including PXR, CAR, LXR, GR, and FXR, which is achieved by the LBD of SHP interacting with the LBD of other nuclear receptors to inhibit their transcriptional activity [110]. Therefore, FXR can indirectly repress the expression of a range of genes by inducing SHP.

\subsection{Activation of Cell-Surface Receptors by BA}

TGR5, also known as GPBAR1 or membrane-type receptor for BA (M-BAR), has been identified as a GPCR for BA by two independent groups [111,112]. TGR5 can be activated by LCA, DCA, CDCA, $\mathrm{CA}$, and taurine or glycine-conjugated forms of these BA. LCA and DCA, which are secondary BA, and conjugated forms of LCA and DCA, are the most potent activators of TGR5 [111], but HDCA and UDCA are also weak activators of TGR5 [101,112,113]. TGR5 is expressed in various tissues, including the small intestine, liver, adipose, spleen, brain, and spinal cord. TGR5 activation is involved with the control of glucose metabolism, neuronal function, and the immune system [63], and its activation by BA regulates a variety of signaling intermediates, including protein kinase A (PKA), Akt/PKB (protein kinase B), and mitogen-activated protein kinases (MAPKs) [114]. Because TGR5 is a G $\alpha_{\mathrm{s}}$-coupled GPCR, the activation of TGR5 stimulates adenylyl cyclase to increase the concentration of cyclic AMP (cAMP), activating PKA and exchange proteins directly activated by cAMP (EPACs) [115]. The activation of TGR5 by BA can also activate both PKA and EPACs [116]. PKA and EPACs activate various signaling pathways, including Akt/PKB and MAPKs [117-119]. Moreover, TGR5 can also associate with $\mathrm{G} \alpha_{\mathrm{i}}$ and $\mathrm{G} \alpha_{\mathrm{q}}$, although TGR5 has been identified to be a $\mathrm{G} \alpha_{\mathrm{s}}$-coupled GPCR [120-122]. In ciliated cholangiocytes, TGR5 is coupled to $G \alpha_{i}$ and the activation of TGR5 results in a decrease in the concentration of cAMP and the activation of extracellular signal-regulated kinases (ERKs). In contrast, TGR5 is coupled to $G \alpha_{\mathrm{s}}$ and the activation of TGR5 results in an increase in the concentration of 
cAMP and the suppression of ERK activation in non-ciliated cholangiocytes [121]. Thus, the signaling pathways influenced by the binding of BA to TGR5 vary according to cell type and cellular conditions. In addition, a recent report has shown that the expression of TGR5 can be induced by FXR in the ileum [123].

S1PR2 is one of five subtypes of S1PR (S1PR1-5). S1P is the ligand for the S1PRs and is generated by the phosphorylation of sphingosine by sphingosine kinase 1 or $2[67,124]$, but BA can also act as ligands for S1PR2. S1PRs are GPCRs, and S1PR2 can couple with $G \alpha_{i}, G \alpha_{q}$, or $G \alpha 12 / 13$ [67]. S1PR2 is expressed in a variety of tissues and its activation influences various signaling molecules, including adenylyl cyclase, Akt/PKB, and MAPKs $[65,67,124]$. An unconjugated BA (DCA) and conjugated BA [TCA, TDCA, tauroursodeoxycholic acid (TUDCA), glycocholic acid (GCA), glycodeoxycholic acid (GDCA), and glycochenodeoxycholic acid (GCDC)] are ligands for S1PR2, binding of which leads to the activation of ERKs and Akt/PKB [125-127].

M2 and M3 muscarinic receptors are GPCRs that are widely distributed and responsible for many of the physiological effects of acetylcholine. They exist in five subtypes $\left(\mathrm{M}_{1}-\mathrm{M}_{5}\right)$, of which the $M_{1}, M_{3}$, and $M_{5}$ receptors couple to $G \alpha_{q}$, while the $M_{2}$ and $M_{4}$ receptors couple to $G \alpha_{i}$ [128]. It has been reported that conjugated BA (TCA, GDCA, and TDCA) are partial agonists of the $\mathrm{M}_{2}$ receptor and activate the $\mathrm{G} \alpha_{\mathrm{i}}$ pathway $[129,130]$, whereas DCA induces the expression of ALDH1, CD166, and Myc via the $\mathrm{M}_{3}$ receptor [131]. TDCA stimulates the relaxation of phenylephrinein-induced constriction in aortic rings, and this TCDCA-stimulated-relaxation is diminished in aortic rings from $\mathrm{M}_{3}$ receptor-knockout mice [132].

FPR is also a GPCR and has various ligands, including bacterially and mitochondrially-derived formyl peptides [68]. FPR couples to $G \alpha_{i}$ and its activation leads to an increase in the mobilization of cellular calcium and the activation of signaling molecules, including MAPKs and Akt/PKB [66,133]. DCA and CDCA also bind to FPR and act as antagonists, suppressing the activation of FPR by formyl N-formyl-met-leu-phe (fMLP), a bacterially-derived FPR ligand [134,135].

\subsection{Activation of Ion Channels by BA}

BASIC is also known as acid-sensing ion channel subunit family member 5 (ASIC5) or intestine $\mathrm{Na}^{+}$channel (INAC) in humans and brain-liver-intestine $\mathrm{Na}^{+}$channel (BLINaC) in rodents. BASIC is a member of the degenerin (DEG)/ENaC ion channel family [72]. CA, UDCA, HDCA, LCA, DCA, and CDCA can activate rodent BASIC. In contrast, only DCA and CDCA can activate human BASIC [136].

$\mathrm{ENaC}$ is also a member of the DEG/ENaC ion channel family and consists of $\alpha, \beta$, and $\gamma$ subunits $[70,71,137]$. In humans, the $\delta$ subunit of $\mathrm{ENaC}$ is highly expressed in the brain, and $\delta \beta \gamma \mathrm{ENaC}$ also exists in this tissue [71,137]. CA, DCA, CDCA, and their taurine conjugates can activate both $\delta \beta \gamma \mathrm{ENaC}$ and $\alpha \beta \gamma \mathrm{ENaC}$ [137].

BK channels are composed of $\alpha$ and $\beta$ subunits, and there are four isotypes of the $\beta$ subunit that can be used. LCA, DCA, and CA activate BK channels, and LCA is the most effective BA in this regard [138]. LCA activates the BK channel by direct interaction with the transmembrane domain of the $\beta 1$ subunit [139]. The $\beta 4$ subunit is the most abundant subunit in the brain, but the $\beta 1$ subunit is also expressed in this tissue [73].

\section{Neurological Functions of BA}

Twenty different BA and their receptors have been identified in the brain, implying that BA have physiological and pathophysiological roles in this tissue (Figure 4), and indeed, many studies of their physiological roles in the brain have been reported. 


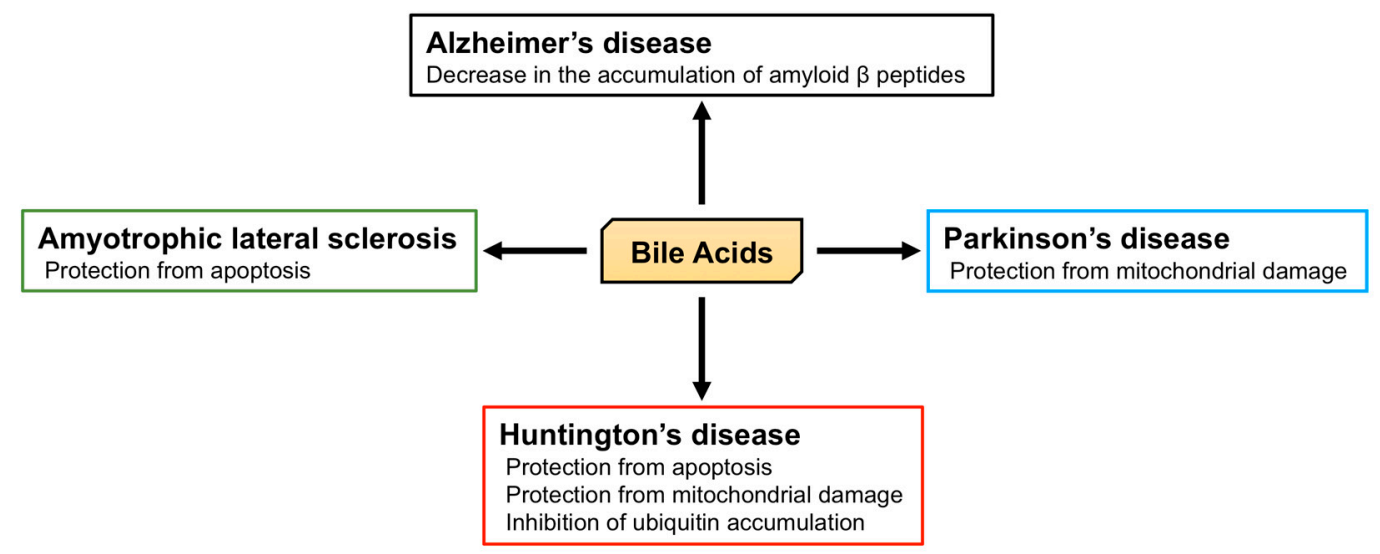

Figure 4. Protective functions of bile acids (BA) against neurodegeneration. BA are known to prevent the accumulation of amyloid $\beta$ peptides in Alzheimer's disease; protect against mitochondrial damage in Parkinson's disease; protect against apoptosis, mitochondrial damage, and ubiquitin accumulation in Huntington's disease; and protect against apoptosis in amyotrophic lateral sclerosis.

\subsection{The Role of BA in the Brain}

BA affect the functioning of the receptors for several neurotransmitters, including $\mathrm{M}_{2}$ and $\mathrm{M}_{3}$ muscarinic acetylcholine receptors, $\gamma$-aminobutyric acid (GABA) type $\mathrm{A}\left(\mathrm{GABA}_{\mathrm{A}}\right)$ receptors, and $\mathrm{N}$-methyl-D-aspartate (NMDA) receptors. TCA, GDCA, and TDCA activate the $\mathrm{M}_{2}$ receptor, while DCA activates the $\mathrm{M}_{3}$ receptor. $\mathrm{M}_{2}$ receptors are distributed throughout the brain and are crucial for cognitive function. However, $\mathrm{M}_{3}$ receptors are localized to neurons, which project to regions such as the hippocampus and substantia nigra, although they are also expressed at low levels throughout the brain. Thus, BA may affect cognitive function, memory, and learning [140]. NMDA receptors are ionotropic glutamate receptors that are activated by the simultaneous binding of both glutamate and D-serine or glycine [141,142]. Their activation causes $\mathrm{Ca}^{2+}$ influx, which can induce long-term potentiation and long-term depression. Therefore, appropriate NMDA receptor activation is important for learning and memory [143]. In contrast, the $\mathrm{GABA}_{\mathrm{A}}$ receptor is an ionotropic GABA receptor that is a ligand-gated chloride ion channel. The activation of $\mathrm{GABA}_{\mathrm{A}}$ receptor causes an influx of chloride ions, leading to the hyperpolarization of neurons and the inhibition of neurotransmission [144]. CDCA, DCA, and CA block both $\mathrm{GABA}_{\mathrm{A}}$ and NMDA receptors [145]. Histaminergic neurons in the tuberomammillary nucleus (TMN) of the hypothalamus play an important role in arousal and wakefulness [146] and express $\mathrm{GABA}_{\mathrm{A}}$ receptors; thus, the suppression of histaminergic neuronal activation in the TMN by GABA induces sleep [147]. Conversely, UDCA increases arousal by blocking $\mathrm{GABA}_{\mathrm{A}}$ receptors on TMN neurons [148]. Moreover, a recent study has demonstrated that TUDCA can induce neurogenesis in adult rats [149]. Adult neurogenesis is the process of generating new functional neurons that are added to the adult brain and occurs in two specific regions: The subgranular zone (SGZ) of the dentate gyrus (DG) in the hippocampus and the subventricular zone (SVZ), located in the walls of the lateral ventricles. Neural stem cells (NSCs) in the SGZ of adult mammals generate neurons in the DG. NSCs in adult human SVZ may produce functional neurons in the striatum by migrating there. In contrast, NSCs in adult rodent SVZ may produce functional neurons in the olfactory bulb [150]. In the rat, TUDCA increases the proliferation and neural differentiation of NSCs in the SVZ, but not in the DG [149].

\subsection{The Role of BA in Neurodegenerative Diseases}

Alzheimer's disease is characterized by memory loss, dementia, and morphological changes in the brain and is a common progressive neurodegenerative disease. The main pathological feature of the brains of patients with Alzheimer's disease is the accumulation of amyloid $\beta$ peptides and tangles of tau protein [151]. The processing of amyloid precursor protein (APP) by $\beta$ and $\gamma$ secretases generates 
amyloid $\beta$ peptide $[152,153]$ and the $\gamma$ secretase complex includes presenilin 1 (PS1), which is associated with the maturation of V-ATPase, responsible for the acidification of lysosomes. PS1 dysfunction, thus, leads to an impairment in lysosomal acidification and function [154,155]. The accumulation of amyloid $\beta$ peptides is relevant to the dysfunction of both APP and $\gamma$ secretase, and APP/PS1 double knockout mice, which express both mutated human APP and PS1, are used as a model of Alzheimer's disease. Interestingly, TUDCA reduces the accumulation of amyloid $\beta$ peptides in the hippocampus and frontal cortex and rescues memory deficits in APP/PS1 double knockout mice [156,157]. In humans, plasma CA concentrations in patients with Alzheimer's disease are significantly lower than those in control subjects, and the TCA concentration in the brain of patients with Alzheimer's disease is also significantly lower [42]. In contrast, the plasma concentration of LCA, a secondary BA, is significantly higher in patients with Alzheimer's disease than in controls [158]. Furthermore, it has been shown that the ratio of DCA (secondary BA) to CA (primary BA) in serum is significantly higher in Alzheimer's patients [159]. These studies indicate the relationship between BA and Alzheimer's disease, and the importance of the brain-gut-microbiome axis. However, morphological and functional abnormalities in mitochondria have also been identified in patients with Alzheimer's disease [160,161]. In fibroblasts from Alzheimer's disease patients, the mitochondrial membrane potential (MMP) is lower, and there is mitochondrial elongation. Dynamin-related protein 1 (DRP1) plays an important role in mitochondrial fission and is essential for mitochondrial quality control [162]. Although the expression of DRP1 is lower in fibroblasts from Alzheimer's disease patients, UDCA increases its expression [163].

Parkinson's disease is another common progressive neurodegenerative disease that is characterized by tremors, muscle stiffness, loss or impairment of voluntary movements, slowness of movement, and postural instability [164]. Mutations in phosphatase and tensin homolog-induced putative kinase 1 (PINK1) and parkin are found in early-onset Parkinson's disease and are important in the progression of Parkinsonism [165-168]. PINK1 and parkin initiate mitophagy and nuclear dot protein 52 kDa (NDP52), and optineurin are essential for this process [169,170]. 1-Methyl-4-phenyl-1,2,3,6-tetrahydropyridine (MPTP) and rotenone treatment have been widely used in the creation of a model of Parkinson's disease. Both toxins inhibit complex I in mitochondria, leading to neuronal mitochondrial damage and Parkinsonism [171,172]. However, TUDCA protects neurons from MPTP-induced oxidative stress and neurotoxicity in the midbrain and striatum of mice [173]. TUDCA induces nuclear factor erythroid 2-related factor 2 (Nrf2) expression and reduces the generation of reactive oxygen species, and indeed, this anti-oxidant effect of TUDCA may be Nrf2-dependent [174]. Moreover, TUDCA ameliorates clinical signs induced by MPTP, such as the increase in swimming latency, foot-dragging, and tremors. In addition, TUDCA inhibits the loss of dopaminergic neurons and reduces the loss of MMP and mitochondrial mass elicited by MPTP [175]. Furthermore, TUDCA increases the expression of PINK1, parkin, and the ratio of LC3-II/1C3-I, implying that TUDCA induces mitophagy [176]. In addition, in the rotenone-induced rat model of Parkinson's disease, UDCA ameliorates abnormalities in the mitochondria of striatal neurons, such as irregular swelling and loss of cristae [177].

Huntington's disease is an autosomal dominant inherited neurodegenerative disease caused by a CAG trinucleotide expansion encoding polyglutamine (polyQ) at the N-terminus of Huntingtin (HTT). Huntington's disease is characterized by motor dysfunction, cognitive decline, and psychiatric disturbances [178,179]. Chemical and genetic models of Huntington's disease have been studied [180,181]. Firstly, 3-nitropropionic acid (3-NP) is an inhibitor of succinate dehydrogenase (complex II) in mitochondria and induces degeneration of the caudate-putamen, which is also present in Huntington's disease [180]. 3-NP treatment is associated with swelling of striatal mitochondria, abnormal mitochondrial membrane structure, and apoptosis. However, TUDCA prevents mitochondrial damage and apoptosis and ameliorates the sensorimotor deficits induced by 3-NP [182]. Secondly, R6/2 transgenic mice possess a genomic fragment containing exon 1 of the human Huntingtin gene, which carries 144 CAG repeats, and are the most widely used model of Huntington's disease [181,183]. In these mice, TUDCA prevents the striatal apoptosis and cerebral and striatal atrophy [184]. The accumulation of HTT and ubiquitin are also symptoms of Huntington's disease, 
and ubiquitin is recruited to polyglutamine-expanded HTT fragments [185]. TUDCA reduces the accumulation of ubiquitin in the striatum of R6/2 transgenic mice and ameliorates their sensorimotor deficits [184].

Amyotrophic lateral sclerosis (ALS) is a progressive and ultimately fatal disease that is characterized by the degeneration of both upper and lower motor neurons, leading to muscle weakness, atrophy, and paralysis [186]. Impairments in superoxide dismutase 1 (SOD1), C9ORF72, TAR DNA-binding protein of $43 \mathrm{kDa}$ (TDP-43), and fused in sarcoma (FUS) are molecular features of this disease [187]. Transgenic mice that carry the glycine 93 to alanine mutation of human SOD1 (hSOD1 ${ }^{\mathrm{G} 93 \mathrm{~A}}$ ) are the most studied model of ALS [188]. NSC-34 cells carrying hSOD1 ${ }^{\mathrm{G} 93 \mathrm{~A}}$ also represent a useful model of ALS-affected motor neurons [189]. Glycoursodeoxycholic acid (GUDCA) prevents the apoptosis of NSC-34 cells carrying hSOD1 ${ }^{\text {G93A }}$ [190], and clinical trials of the use of TUDCA in patients with ALS have shown an improvement in muscle function and survival time, without adverse effects [191].

\section{Concluding Remarks}

The existence of $20 \mathrm{BA}$ in the brain has been demonstrated. These $20 \mathrm{BA}$ include uncojugated BA (CA, CDCA, DCA, and UDCA) and conjugated BA (GDCA, TCA, TDCA, and TUDCA), which are related to the brain physiology and/or to pathophysiology [6]. In addition, receptors and ion channels that are activated by BA are also expressed in this tissue. These findings imply that BA have a neurological function. The effects of several BA to protect against neurodegeneration are associated with inhibition of the accumulation of amyloid $\beta$ peptides, mitochondrial damage, and apoptosis. However, BA have been shown to activate many receptors and ion channels, through which they may also play a neuroprotective role. Especially, TUDCA is the bile acid with the most diversity of actions on the human organism. Although the mechanism whereby TUDCA might induce adult neurogenesis remains unclear, it is possible that other BA also affect neurogenesis. Neuroprotective effects and the induction of adult neurogenesis represent important approaches to the therapy of neurogenerative diseases and brain injury. Both conjugated and unconjugated BA can enter the brain by crossing the BBB or using transporters. Moreover, UDCA, which is approved by the US Food and Drug Administration for the treatment of primary biliary cirrhosis [192], can enter the cerebrospinal fluid after oral administration [193]. Thus, the oral administration of BA may represent a feasible approach for the treatment of neurodegenerative diseases and brain injury in the future.

Elucidation of the detailed mechanisms involved in the synthesis, signaling, and physiological functions of BA in the brain should help the development of novel therapeutic and diagnostic strategies for brain diseases.

Author Contributions: Y.K. and H.N. contributed to the writing of the review.

Funding: This research received no external funding.

Conflicts of Interest: The authors declare no conflict of interest.

\section{References}

1. Thomas, C.; Pellicciari, R.; Pruzanski, M.; Auwerx, J.; Schoonjans, K. Targeting bile-acid signalling for metabolic diseases. Nat. Rev. Drug Discov. 2008, 7, 678-693. [CrossRef] [PubMed]

2. Hofmann, A.F.; Hagey, L.R.; Krasowski, M.D. Bile salts of vertebrates: Structural variation and possible evolutionary significance. J. Lipid Res. 2010, 51, 226-246. [CrossRef] [PubMed]

3. Reschly, E.J.; Ai, N.; Ekins, S.; Welsh, W.J.; Hagey, L.R.; Hofmann, A.F.; Krasowski, M.D. Evolution of the bile salt nuclear receptor FXR in vertebrates. J. Lipid Res. 2008, 49, 1577-1587. [CrossRef] [PubMed]

4. Molinaro, A.; Wahlstrom, A.; Marschall, H.U. Role of Bile Acids in Metabolic Control. Trends Endocrinol. Metab. 2018, 29, 31-41. [CrossRef]

5. Mano, N.; Goto, T.; Uchida, M.; Nishimura, K.; Ando, M.; Kobayashi, N.; Goto, J. Presence of protein-bound unconjugated bile acids in the cytoplasmic fraction of rat brain. J. Lipid Res. 2004, 45, 295-300. [CrossRef] [PubMed] 
6. Zheng, X.; Chen, T.; Zhao, A.; Wang, X.; Xie, G.; Huang, F.; Liu, J.; Zhao, Q.; Wang, S.; Wang, C.; et al. The Brain Metabolome of Male Rats across the Lifespan. Sci Rep. 2016, 6, 24125. [CrossRef] [PubMed]

7. Chiang, J.Y. Bile acids: Regulation of synthesis. J. Lipid Res. 2009, 50, 1955-1966. [CrossRef]

8. Russell, D.W. Fifty years of advances in bile acid synthesis and metabolism. J. Lipid Res. 2009, 50, S120-125. [CrossRef]

9. Fakheri, R.J.; Javitt, N.B. 27-Hydroxycholesterol, does it exist? On the nomenclature and stereochemistry of 26-hydroxylated sterols. Steroids 2012, 77, 575-577. [CrossRef]

10. De Aguiar Vallim, T.Q.; Tarling, E.J.; Edwards, P.A. Pleiotropic roles of bile acids in metabolism. Cell Metab. 2013, 17, 657-669. [CrossRef]

11. Bathena, S.P.; Mukherjee, S.; Olivera, M.; Alnouti, Y. The profile of bile acids and their sulfate metabolites in human urine and serum. J. Chromatogr. B Analyt. Technol. Biomed. Life Sci. 2013, 942-943, 53-62. [CrossRef] [PubMed]

12. Nakashima, T.; Sano, A.; Seto, Y.; Nakajima, T.; Nakagawa, Y.; Okuno, T.; Takino, T.; Hasegawa, T. Unusual trihydroxy bile acids in the urine of healthy humans. Clin. Chim. Acta 1986, 160, 47-53. [CrossRef]

13. Li, T.; Apte, U. Bile Acid Metabolism and Signaling in Cholestasis, Inflammation, and Cancer. Adv. Pharmacol. 2015, 74, 263-302. [PubMed]

14. Trauner, M.; Boyer, J.L. Bile salt transporters: Molecular characterization, function, and regulation. Physiol. Rev. 2003, 83, 633-671. [CrossRef] [PubMed]

15. Chikai, T.; Nakao, H.; Uchida, K. Deconjugation of bile acids by human intestinal bacteria implanted in germ-free rats. Lipids 1987, 22, 669-671. [CrossRef]

16. Begley, M.; Gahan, C.G.; Hill, C. The interaction between bacteria and bile. FEMS Microbiol. Rev. 2005, 29, 625-651. [CrossRef] [PubMed]

17. Lepercq, P.; Gerard, P.; Beguet, F.; Raibaud, P.; Grill, J.P.; Relano, P.; Cayuela, C.; Juste, C. Epimerization of chenodeoxycholic acid to ursodeoxycholic acid by Clostridium baratii isolated from human feces. FEMS Microbiol. Lett. 2004, 235. [CrossRef]

18. Martin, F.P.; Dumas, M.E.; Wang, Y.; Legido-Quigley, C.; Yap, I.K.; Tang, H.; Zirah, S.; Murphy, G.M.; Cloarec, O.; Lindon, J.C.; et al. A top-down systems biology view of microbiome-mammalian metabolic interactions in a mouse model. Mol. Syst. Biol. 2007, 3, 112. [CrossRef]

19. Fu, Z.D.; Csanaky, I.L.; Klaassen, C.D. Gender-divergent profile of bile acid homeostasis during aging of mice. PLoS ONE 2012, 7, e32551. [CrossRef]

20. Chiang, J.Y. Bile acid metabolism and signaling. Compr. Physiol. 2013, 3, 1191-1212.

21. Dawson, P.A.; Karpen, S.J. Intestinal transport and metabolism of bile acids. J. Lipid Res. 2015, 56, 1085-1099. [CrossRef] [PubMed]

22. Oelkers, P.; Kirby, L.C.; Heubi, J.E.; Dawson, P.A. Primary bile acid malabsorption caused by mutations in the ileal sodium-dependent bile acid transporter gene (SLC10A2). J. Clin. Invest. 1997, 99, 1880-1887. [CrossRef] [PubMed]

23. Meier, Y.; Eloranta, J.J.; Darimont, J.; Ismair, M.G.; Hiller, C.; Fried, M.; Kullak-Ublick, G.A.; Vavricka, S.R. Regional distribution of solute carrier mRNA expression along the human intestinal tract. Drug Metab. Dispos. 2007, 35, 590-594. [CrossRef] [PubMed]

24. Shneider, B.L.; Dawson, P.A.; Christie, D.M.; Hardikar, W.; Wong, M.H.; Suchy, F.J. Cloning and molecular characterization of the ontogeny of a rat ileal sodium-dependent bile acid transporter. J. Clin. Invest. 1995, 95, 745-754. [CrossRef] [PubMed]

25. Christie, D.M.; Dawson, P.A.; Thevananther, S.; Shneider, B.L. Comparative analysis of the ontogeny of a sodium-dependent bile acid transporter in rat kidney and ileum. Am. J. Physiol. 1996, 271, G377-G385. [CrossRef] [PubMed]

26. Kiriyama, Y.; Nochi, H. Role and Cytotoxicity of Amylin and Protection of Pancreatic Islet $\beta$-Cells from Amylin Cytotoxicity. Cells 2018, 7, 95. [CrossRef] [PubMed]

27. Wali, J.A.; Masters, S.L.; Thomas, H.E. Linking metabolic abnormalities to apoptotic pathways in Beta cells in type 2 diabetes. Cells 2013, 2, 266-283. [CrossRef]

28. Tuomi, T.; Santoro, N.; Caprio, S.; Cai, M.; Weng, J.; Groop, L. The many faces of diabetes: A disease with increasing heterogeneity. Lancet 2014, 383, 1084-1094. [CrossRef]

29. Kahn, S.E.; Cooper, M.E.; Del Prato, S. Pathophysiology and treatment of type 2 diabetes: Perspectives on the past, present, and future. Lancet 2014, 383, 1068-1083. [CrossRef] 
30. Hansen, M.; Sonne, D.P.; Mikkelsen, K.H.; Gluud, L.L.; Vilsboll, T.; Knop, F.K. Bile acid sequestrants for glycemic control in patients with type 2 diabetes: A systematic review with meta-analysis of randomized controlled trials. J. Diabetes Complicat. 2017, 31, 918-927. [CrossRef]

31. Wu, Y.; Aquino, C.J.; Cowan, D.J.; Anderson, D.L.; Ambroso, J.L.; Bishop, M.J.; Boros, E.E.; Chen, L.; Cunningham, A.; Dobbins, R.L.; et al. Discovery of a highly potent, nonabsorbable apical sodium-dependent bile acid transporter inhibitor (GSK2330672) for treatment of type 2 diabetes. J. Med. Chem 2013, 56, 5094-5114. [CrossRef] [PubMed]

32. Lin, M.C.; Kramer, W.; Wilson, F.A. Identification of cytosolic and microsomal bile acid-binding proteins in rat ileal enterocytes. J. Biol. Chem. 1990, 265, 14986-14995. [PubMed]

33. Christian, W.V.; Li, N.; Hinkle, P.M.; Ballatori, N. $\beta$-Subunit of the Ostalpha-Ostbeta organic solute transporter is required not only for heterodimerization and trafficking but also for function. J. Biol. Chem. 2012, 287, 21233-21243. [CrossRef] [PubMed]

34. Ballatori, N.; Christian, W.V.; Lee, J.Y.; Dawson, P.A.; Soroka, C.J.; Boyer, J.L.; Madejczyk, M.S.; Li, N. OSTalpha-OSTbeta: A major basolateral bile acid and steroid transporter in human intestinal, renal, and biliary epithelia. Hepatology 2005, 42, 1270-1279. [CrossRef] [PubMed]

35. Dawson, P.A.; Hubbert, M.; Haywood, J.; Craddock, A.L.; Zerangue, N.; Christian, W.V.; Ballatori, N. The heteromeric organic solute transporter alpha-beta, Ostalpha-Ostbeta, is an ileal basolateral bile acid transporter. J. Biol. Chem. 2005, 280, 6960-6968. [CrossRef] [PubMed]

36. Ananthanarayanan, M.; Ng, O.C.; Boyer, J.L.; Suchy, F.J. Characterization of cloned rat liver Na(+)-bile acid cotransporter using peptide and fusion protein antibodies. Am. J. Physiol 1994, 267, G637-G643. [CrossRef] [PubMed]

37. Stieger, B.; Hagenbuch, B.; Landmann, L.; Hochli, M.; Schroeder, A.; Meier, P.J. In situ localization of the hepatocytic Na+/Taurocholate cotransporting polypeptide in rat liver. Gastroenterology 1994, 107, 1781-1787. [CrossRef]

38. Hagenbuch, B.; Scharschmidt, B.F.; Meier, P.J. Effect of antisense oligonucleotides on the expression of hepatocellular bile acid and organic anion uptake systems in Xenopus laevis oocytes. Biochem J. 1996, 316, 901-904. [CrossRef]

39. Nigam, S.K.; Bush, K.T.; Martovetsky, G.; Ahn, S.Y.; Liu, H.C.; Richard, E.; Bhatnagar, V.; Wu, W. The organic anion transporter (OAT) family: A systems biology perspective. Physiol. Rev. 2015, 95, 83-123. [CrossRef]

40. Csanaky, I.L.; Lu, H.; Zhang, Y.; Ogura, K.; Choudhuri, S.; Klaassen, C.D. Organic anion-transporting polypeptide $1 \mathrm{~b} 2$ (Oatp1b2) is important for the hepatic uptake of unconjugated bile acids: Studies in Oatp1b2-null mice. Hepatology 2011, 53, 272-281. [CrossRef]

41. Suga, T.; Yamaguchi, H.; Sato, T.; Maekawa, M.; Goto, J.; Mano, N. Preference of Conjugated Bile Acids over Unconjugated Bile Acids as Substrates for OATP1B1 and OATP1B3. PLoS ONE 2017, 12, e0169719. [CrossRef] [PubMed]

42. Pan, X.; Elliott, C.T.; McGuinness, B.; Passmore, P.; Kehoe, P.G.; Holscher, C.; McClean, P.L.; Graham, S.F.; Green, B.D. Metabolomic Profiling of Bile Acids in Clinical and Experimental Samples of Alzheimer's Disease. Metabolites 2017, 7, 28. [CrossRef] [PubMed]

43. Xie, G.; Zhong, W.; Li, H.; Li, Q.; Qiu, Y.; Zheng, X.; Chen, H.; Zhao, X.; Zhang, S.; Zhou, Z.; et al. Alteration of bile acid metabolism in the rat induced by chronic ethanol consumption. FASEB J. 2013, 27, 3583-3593. [CrossRef] [PubMed]

44. Benedetti, A.; Di Sario, A.; Marucci, L.; Svegliati-Baroni, G.; Schteingart, C.D.; Ton-Nu, H.T.; Hofmann, A.F. Carrier-mediated transport of conjugated bile acids across the basolateral membrane of biliary epithelial cells. Am. J. Physiol. 1997, 272, G1416-G1424. [CrossRef] [PubMed]

45. St-Pierre, M.V.; Kullak-Ublick, G.A.; Hagenbuch, B.; Meier, P.J. Transport of bile acids in hepatic and non-hepatic tissues. J. Exp. Biol. 2001, 204, 1673-1686. [PubMed]

46. Choudhuri, S.; Cherrington, N.J.; Li, N.; Klaassen, C.D. Constitutive expression of various xenobiotic and endobiotic transporter mRNAs in the choroid plexus of rats. Drug Metab. Dispos. 2003, 31, 1337-1345. [CrossRef]

47. Bauer, B.; Hartz, A.M.; Lucking, J.R.; Yang, X.; Pollack, G.M.; Miller, D.S. Coordinated nuclear receptor regulation of the efflux transporter, Mrp2, and the phase-II metabolizing enzyme, GSTpi, at the blood-brain barrier. J. Cereb. Blood Flow Metab. 2008, 28, 1222-1234. [CrossRef] 
48. Angeletti, R.H.; Novikoff, P.M.; Juvvadi, S.R.; Fritschy, J.M.; Meier, P.J.; Wolkoff, A.W. The choroid plexus epithelium is the site of the organic anion transport protein in the brain. Proc. Natl. Acad. Sci. USA 1997, 94, 283-286. [CrossRef]

49. Luissint, A.C.; Artus, C.; Glacial, F.; Ganeshamoorthy, K.; Couraud, P.O. Tight junctions at the blood brain barrier: Physiological architecture and disease-associated dysregulation. Fluids Barriers CNS 2012, 9, 23. [CrossRef]

50. Rao, R. Occludin phosphorylation in regulation of epithelial tight junctions. Ann. N Y Acad. Sci. 2009, 1165, 62-68. [CrossRef]

51. Quinn, M.; McMillin, M.; Galindo, C.; Frampton, G.; Pae, H.Y.; DeMorrow, S. Bile acids permeabilize the blood brain barrier after bile duct ligation in rats via Rac1-dependent mechanisms. Dig. Liver Dis. 2014, 46, 527-534. [CrossRef]

52. Hanafi, N.I.; Mohamed, A.S.; Sheikh Abdul Kadir, S.H.; Othman, M.H.D. Overview of Bile Acids Signaling and Perspective on the Signal of Ursodeoxycholic Acid, the Most Hydrophilic Bile Acid, in the Heart. Biomolecules 2018, 8, 159. [CrossRef]

53. Higashi, T.; Watanabe, S.; Tomaru, K.; Yamazaki, W.; Yoshizawa, K.; Ogawa, S.; Nagao, H.; Minato, K.; Maekawa, M.; Mano, N. Unconjugated bile acids in rat brain: Analytical method based on LC/ESI-MS/MS with chemical derivatization and estimation of their origin by comparison to serum levels. Steroids 2017, 125, 107-113. [CrossRef]

54. Kamp, F.; Hamilton, J.A.; Kamp, F.; Westerhoff, H.V.; Hamilton, J.A. Movement of fatty acids, fatty acid analogues, and bile acids across phospholipid bilayers. Biochemistry 1993, 32, 11074-11086. [CrossRef]

55. Smith, L.L.; Ray, D.R.; Moody, J.A.; Wells, J.D.; Van Lier, J.E. 24-hydroxycholesterol levels in human brain. J. Neurochem. 1972, 19, 899-904. [CrossRef]

56. Meljon, A.; Theofilopoulos, S.; Shackleton, C.H.; Watson, G.L.; Javitt, N.B.; Knolker, H.J.; Saini, R.; Arenas, E.; Wang, Y.; Griffiths, W.J. Analysis of bioactive oxysterols in newborn mouse brain by LC/MS. J. Lipid Res. 2012, 53, 2469-2483. [CrossRef]

57. Lutjohann, D.; Breuer, O.; Ahlborg, G.; Nennesmo, I.; Siden, A.; Diczfalusy, U.; Bjorkhem, I. Cholesterol homeostasis in human brain: Evidence for an age-dependent flux of 24S-hydroxycholesterol from the brain into the circulation. Proc. Natl. Acad. Sci. USA 1996, 93, 9799-9804. [CrossRef]

58. Lund, E.G.; Xie, C.; Kotti, T.; Turley, S.D.; Dietschy, J.M.; Russell, D.W. Knockout of the cholesterol 24-hydroxylase gene in mice reveals a brain-specific mechanism of cholesterol turnover. J. Biol. Chem. 2003, 278, 22980-22988. [CrossRef]

59. Mano, N.; Sato, Y.; Nagata, M.; Goto, T.; Goto, J. Bioconversion of 3beta-hydroxy-5-cholenoic acid into chenodeoxycholic acid by rat brain enzyme systems. J. Lipid Res. 2004, 45, 1741-1748. [CrossRef]

60. Heverin, M.; Meaney, S.; Lutjohann, D.; Diczfalusy, U.; Wahren, J.; Bjorkhem, I. Crossing the barrier: Net flux of 27-hydroxycholesterol into the human brain. J. Lipid Res. 2005, 46, 1047-1052. [CrossRef]

61. Olivares, A.M.; Moreno-Ramos, O.A.; Haider, N.B. Role of Nuclear Receptors in Central Nervous System Development and Associated Diseases. J. Exp. Neurosci. 2015, 9, 93-121.

62. Frye, C.A.; Paris, J.J.; Walf, A.A.; Rusconi, J.C. Effects and Mechanisms of 3alpha,5alpha, -THP on Emotion, Motivation, and Reward Functions Involving Pregnane Xenobiotic Receptor. Front. Neurosci. 2011, 5, 136.

63. Duboc, H.; Tache, Y.; Hofmann, A.F. The bile acid TGR5 membrane receptor: From basic research to clinical application. Dig. Liver Dis. 2014, 46, 302-312. [CrossRef]

64. Huang, Y.; Thathiah, A. Regulation of neuronal communication by G protein-coupled receptors. FEBS Lett. 2015, 589, 1607-1619. [CrossRef]

65. Tayebati, S.K. Phospholipid and Lipid Derivatives as Potential Neuroprotective Compounds. Molecules 2018, 23, 2257. [CrossRef]

66. Cattaneo, F.; Guerra, G.; Ammendola, R. Expression and signaling of formyl-peptide receptors in the brain. Neurochem. Res. 2010, 35, 2018-2026. [CrossRef]

67. Healy, L.M.; Antel, J.P. Sphingosine-1-Phosphate Receptors in the Central Nervous and Immune Systems. Curr. Drug Targets 2016, 17, 1841-1850. [CrossRef]

68. He, H.Q.; Ye, R.D. The Formyl Peptide Receptors: Diversity of Ligands and Mechanism for Recognition. Molecules 2017, 22, 455. [CrossRef] 
69. Latorre, R.; Castillo, K.; Carrasquel-Ursulaez, W.; Sepulveda, R.V.; Gonzalez-Nilo, F.; Gonzalez, C.; Alvarez, O. Molecular Determinants of BK Channel Functional Diversity and Functioning. Physiol. Rev. 2017, 97, 39-87. [CrossRef]

70. Wiemuth, D.; Assmann, M.; Grunder, S. The bile acid-sensitive ion channel (BASIC), the ignored cousin of ASICs and ENaC. Channels (Austin) 2014, 8, 29-34. [CrossRef]

71. Giraldez, T.; Afonso-Oramas, D.; Cruz-Muros, I.; Garcia-Marin, V.; Pagel, P.; Gonzalez-Hernandez, T.; Alvarez de la Rosa, D. Cloning and functional expression of a new epithelial sodium channel delta subunit isoform differentially expressed in neurons of the human and monkey telencephalon. J. Neurochem. 2007, 102, 1304-1315. [CrossRef]

72. Kellenberger, S.; Schild, L. International Union of Basic and Clinical Pharmacology. XCI. structure, function, and pharmacology of acid-sensing ion channels and the epithelial Na+ channel. Pharmacol. Rev. 2015, 67, 1-35. [CrossRef]

73. Contet, C.; Goulding, S.P.; Kuljis, D.A.; Barth, A.L. BK Channels in the Central Nervous System. Int. Rev. Neurobiol. 2016, 128, 281-342.

74. Wang, H.; Chen, J.; Hollister, K.; Sowers, L.C.; Forman, B.M. Endogenous bile acids are ligands for the nuclear receptor FXR/BAR. Mol. Cell 1999, 3, 543-553. [CrossRef]

75. Makishima, M.; Okamoto, A.Y.; Repa, J.J.; Tu, H.; Learned, R.M.; Luk, A.; Hull, M.V.; Lustig, K.D.; Mangelsdorf, D.J.; Shan, B. Identification of a nuclear receptor for bile acids. Science 1999, 284, 1362-1365. [CrossRef]

76. Parks, D.J.; Blanchard,S.G.; Bledsoe, R.K.; Chandra, G.; Consler, T.G.; Kliewer, S.A.; Stimmel, J.B.; Willson, T.M.; Zavacki, A.M.; Moore, D.D.; et al. Bile acids: Natural ligands for an orphan nuclear receptor. Science 1999, 284, 1365-1368. [CrossRef]

77. Jiang, C.; Xie, C.; Lv, Y.; Li, J.; Krausz, K.W.; Shi, J.; Brocker, C.N.; Desai, D.; Amin, S.G.; Bisson, W.H.; et al. Intestine-selective farnesoid $X$ receptor inhibition improves obesity-related metabolic dysfunction. Nat. Commun. 2015, 6, 10166. [CrossRef]

78. Li, F.; Jiang, C.; Krausz, K.W.; Li, Y.; Albert, I.; Hao, H.; Fabre, K.M.; Mitchell, J.B.; Patterson, A.D.; Gonzalez, F.J. Microbiome remodelling leads to inhibition of intestinal farnesoid $\mathrm{X}$ receptor signalling and decreased obesity. Nat. Commun. 2013, 4, 2384. [CrossRef]

79. Sayin, S.I.; Wahlstrom, A.; Felin, J.; Jantti, S.; Marschall, H.U.; Bamberg, K.; Angelin, B.; Hyotylainen, T.; Oresic, M.; Backhed, F. Gut microbiota regulates bile acid metabolism by reducing the levels of tauro-beta-muricholic acid, a naturally occurring FXR antagonist. Cell Metab. 2013, 17, 225-235. [CrossRef]

80. Thomas, A.M.; Hart, S.N.; Kong, B.; Fang, J.; Zhong, X.B.; Guo, G.L. Genome-wide tissue-specific farnesoid X receptor binding in mouse liver and intestine. Hepatology 2010, 51, 1410-1419. [CrossRef]

81. Edwards, P.A.; Kast, H.R.; Anisfeld, A.M. BAREing it all: The adoption of LXR and FXR and their roles in lipid homeostasis. J. Lipid Res. 2002, 43, 2-12.

82. Seol, W.; Choi, H.S.; Moore, D.D. Isolation of proteins that interact specifically with the retinoid X receptor: Two novel orphan receptors. Mol. Endocrinol. 1995, 9, 72-85.

83. Laffitte, B.A.; Kast, H.R.; Nguyen, C.M.; Zavacki, A.M.; Moore, D.D.; Edwards, P.A. Identification of the DNA binding specificity and potential target genes for the farnesoid X-activated receptor. J. Biol. Chem. 2000, 275, 10638-10647. [CrossRef]

84. Kast, H.R.; Goodwin, B.; Tarr, P.T.; Jones, S.A.; Anisfeld, A.M.; Stoltz, C.M.; Tontonoz, P.; Kliewer, S.; Willson, T.M.; Edwards, P.A. Regulation of multidrug resistance-associated protein 2 (ABCC2) by the nuclear receptors pregnane $\mathrm{X}$ receptor, farnesoid $\mathrm{X}$-activated receptor, and constitutive androstane receptor. J. Biol. Chem. 2002, 277, 2908-2915. [CrossRef]

85. Evans, R.M.; Mangelsdorf, D.J. Nuclear Receptors, RXR, and the Big Bang. Cell 2014, 157, 255-266. [CrossRef]

86. Ihunnah, C.A.; Jiang, M.; Xie, W. Nuclear receptor PXR, transcriptional circuits and metabolic relevance. Biochim. Biophys. Acta 2011, 1812, 956-963. [CrossRef]

87. Willson, T.M.; Kliewer, S.A. PXR, CAR and drug metabolism. Nat. Rev. Drug Discov. 2002, 1, $259-266$. [CrossRef]

88. Schuster, D.; Langer, T. The identification of ligand features essential for PXR activation by pharmacophore modeling. J. Chem. Inf. Model. 2005, 45, 431-439. [CrossRef]

89. Kliewer, S.A.; Goodwin, B.; Willson, T.M. The nuclear pregnane X receptor: A key regulator of xenobiotic metabolism. Endocr. Rev. 2002, 23, 687-702. [CrossRef] 
90. Staudinger, J.L.; Goodwin, B.; Jones, S.A.; Hawkins-Brown, D.; MacKenzie, K.I.; LaTour, A.; Liu, Y.; Klaassen, C.D.; Brown, K.K.; Reinhard, J.; et al. The nuclear receptor PXR is a lithocholic acid sensor that protects against liver toxicity. Proc. Natl. Acad. Sci. USA 2001, 98, 3369-3374. [CrossRef]

91. Staudinger, J.; Liu, Y.; Madan, A.; Habeebu, S.; Klaassen, C.D. Coordinate regulation of xenobiotic and bile acid homeostasis by pregnane $\mathrm{X}$ receptor. Drug Metab. Dispos. 2001, 29, 1467-1472.

92. Xie, W.; Barwick, J.L.; Simon, C.M.; Pierce, A.M.; Safe, S.; Blumberg, B.; Guzelian, P.S.; Evans, R.M. Reciprocal activation of xenobiotic response genes by nuclear receptors SXR/PXR and CAR. Genes Dev. 2000, 14, 3014-3023. [CrossRef]

93. Li, T.; Chiang, J.Y. Mechanism of rifampicin and pregnane X receptor inhibition of human cholesterol 7 alpha-hydroxylase gene transcription. Am. J. Physiol. Gastrointest. Liver Physiol. 2005, 288, G74-G84. [CrossRef]

94. Bhalla, S.; Ozalp, C.; Fang, S.; Xiang, L.; Kemper, J.K. Ligand-activated pregnane X receptor interferes with HNF-4 signaling by targeting a common coactivator PGC-1alpha. Functional implications in hepatic cholesterol and glucose metabolism. J. Biol. Chem. 2004, 279, 45139-45147. [CrossRef]

95. Jung, D.; Mangelsdorf, D.J.; Meyer, U.A. Pregnane X receptor is a target of farnesoid X receptor. J. Biol. Chem. 2006, 281, 19081-19091. [CrossRef]

96. Masuno, H.; Ikura, T.; Morizono, D.; Orita, I.; Yamada, S.; Shimizu, M.; Ito, N. Crystal structures of complexes of vitamin D receptor ligand-binding domain with lithocholic acid derivatives. J. Lipid Res. 2013, 54, 2206-2213. [CrossRef]

97. Makishima, M.; Lu, T.T.; Xie, W.; Whitfield, G.K.; Domoto, H.; Evans, R.M.; Haussler, M.R.; Mangelsdorf, D.J. Vitamin D receptor as an intestinal bile acid sensor. Science 2002, 296, 1313-1316. [CrossRef]

98. McCarthy, T.C.; Li, X.; Sinal, C.J. Vitamin D receptor-dependent regulation of colon multidrug resistance-associated protein 3 gene expression by bile acids. J. Biol. Chem. 2005, 280, 23232-23242. [CrossRef]

99. Pavek, P.; Pospechova, K.; Svecova, L.; Syrova, Z.; Stejskalova, L.; Blazkova, J.; Dvorak, Z.; Blahos, J. Intestinal cell-specific vitamin D receptor (VDR)-mediated transcriptional regulation of CYP3A4 gene. Biochem. Pharmacol. 2010, 79, 277-287. [CrossRef]

100. Matsubara, T.; Yoshinari, K.; Aoyama, K.; Sugawara, M.; Sekiya, Y.; Nagata, K.; Yamazoe, Y. Role of vitamin D receptor in the lithocholic acid-mediated CYP3A induction in vitro and in vivo. Drug Metab. Dispos. 2008, 36, 2058-2063. [CrossRef]

101. De Marino, S.; Carino, A.; Masullo, D.; Finamore, C.; Marchiano, S.; Cipriani, S.; Di Leva, F.S.; Catalanotti, B.; Novellino, E.; Limongelli, V.; et al. Hyodeoxycholic acid derivatives as liver $\mathrm{X}$ receptor alpha and G-protein-coupled bile acid receptor agonists. Sci. Rep. 2017, 7, 43290. [CrossRef]

102. Song, C.; Hiipakka, R.A.; Liao, S. Selective activation of liver $X$ receptor alpha by 6alpha-hydroxy bile acids and analogs. Steroids 2000, 65, 423-427. [CrossRef]

103. Peet, D.J.; Turley, S.D.; Ma, W.; Janowski, B.A.; Lobaccaro, J.M.; Hammer, R.E.; Mangelsdorf, D.J. Cholesterol and bile acid metabolism are impaired in mice lacking the nuclear oxysterol receptor LXR alpha. Cell 1998, 93, 693-704. [CrossRef]

104. Alberti, S.; Schuster, G.; Parini, P.; Feltkamp, D.; Diczfalusy, U.; Rudling, M.; Angelin, B.; Bjorkhem, I.; Pettersson, S.; Gustafsson, J.A. Hepatic cholesterol metabolism and resistance to dietary cholesterol in LXRbeta-deficient mice. J. Clin. Invest. 2001, 107, 565-573. [CrossRef]

105. Gupta, S.; Pandak, W.M.; Hylemon, P.B. LXR alpha is the dominant regulator of CYP7A1 transcription. Biochem. Biophys Res. Commun. 2002, 293, 338-343. [CrossRef]

106. Kadmiel, M.; Cidlowski, J.A. Glucocorticoid receptor signaling in health and disease. Trends Pharmacol. Sci. 2013, 34, 518-530. [CrossRef]

107. McMillin, M.; Frampton, G.; Quinn, M.; Divan, A.; Grant, S.; Patel, N.; Newell-Rogers, K.; DeMorrow, S. Suppression of the HPA Axis During Cholestasis Can Be Attributed to Hypothalamic Bile Acid Signaling. Mol. Endocrinol. 2015, 29, 1720-1730. [CrossRef]

108. Miura, T.; Ouchida, R.; Yoshikawa, N.; Okamoto, K.; Makino, Y.; Nakamura, T.; Morimoto, C.; Makino, I.; Tanaka, H. Functional modulation of the glucocorticoid receptor and suppression of NF-kappaB-dependent transcription by ursodeoxycholic acid. J. Biol. Chem. 2001, 276, 47371-47378. [CrossRef]

109. Huang, C.; Wang, J.; Hu, W.; Wang, C.; Lu, X.; Tong, L.; Wu, F.; Zhang, W. Identification of functional farnesoid $X$ receptors in brain neurons. FEBS Lett. 2016, 590, 3233-3242. [CrossRef] 
110. Zhang, Y.; Hagedorn, C.H.; Wang, L. Role of nuclear receptor SHP in metabolism and cancer. Biochim. Biophys. Acta 2011, 1812, 893-908. [CrossRef]

111. Maruyama, T.; Miyamoto, Y.; Nakamura, T.; Tamai, Y.; Okada, H.; Sugiyama, E.; Nakamura, T.; Itadani, H.; Tanaka, K. Identification of membrane-type receptor for bile acids (M-BAR). Biochem. Biophys. Res. Commun. 2002, 298, 714-719. [CrossRef]

112. Kawamata, Y.; Fujii, R.; Hosoya, M.; Harada, M.; Yoshida, H.; Miwa, M.; Fukusumi, S.; Habata, Y.; Itoh, T.; Shintani, Y.; et al. A G protein-coupled receptor responsive to bile acids. J. Biol. Chem. 2003, 278, 9435-9440. [CrossRef]

113. Sato, H.; Macchiarulo, A.; Thomas, C.; Gioiello, A.; Une, M.; Hofmann, A.F.; Saladin, R.; Schoonjans, K.; Pellicciari, R.; Auwerx, J. Novel potent and selective bile acid derivatives as TGR5 agonists: Biological screening, structure-activity relationships, and molecular modeling studies. J. Med. Chem. 2008, 51, 1831-1841. [CrossRef]

114. Guo, C.; Chen, W.D.; Wang, Y.D. TGR5, Not Only a Metabolic Regulator. Front. Physiol. 2016, 7, 646. [CrossRef]

115. Gancedo, J.M. Biological roles of cAMP: Variations on a theme in the different kingdoms of life. Biol. Rev. Camb. Philos. Soc. 2013, 88, 645-668. [CrossRef]

116. Kumar, D.P.; Asgharpour, A.; Mirshahi, F.; Park, S.H.; Liu, S.; Imai, Y.; Nadler, J.L.; Grider, J.R.; Murthy, K.S.; Sanyal, A.J. Activation of Transmembrane Bile Acid Receptor TGR5 Modulates Pancreatic Islet alpha Cells to Promote Glucose Homeostasis. J. Biol. Chem. 2016, 291, 6626-6640. [CrossRef]

117. Laurent, A.C.; Breckler, M.; Berthouze, M.; Lezoualc'h, F. Role of Epac in brain and heart. Biochem. Soc. Trans. 2012, 40, 51-57. [CrossRef]

118. Roscioni, S.S.; Elzinga, C.R.; Schmidt, M. Epac: Effectors and biological functions. Naunyn Schmiedebergs Arch. Pharmacol. 2008, 377, 345-357. [CrossRef]

119. Robichaux, W.G., 3rd; Cheng, X. Intracellular cAMP Sensor EPAC: Physiology, Pathophysiology, and Therapeutics Development. Physiol. Rev. 2018, 98, 919-1053. [CrossRef]

120. Hong, J.; Behar, J.; Wands, J.; Resnick, M.; Wang, L.J.; DeLellis, R.A.; Lambeth, D.; Souza, R.F.; Spechler, S.J.; Cao, W. Role of a novel bile acid receptor TGR5 in the development of oesophageal adenocarcinoma. Gut 2010, 59, 170-180. [CrossRef]

121. Masyuk, A.I.; Huang, B.Q.; Radtke, B.N.; Gajdos, G.B.; Splinter, P.L.; Masyuk, T.V.; Gradilone, S.A.; LaRusso, N.F. Ciliary subcellular localization of TGR5 determines the cholangiocyte functional response to bile acid signaling. Am. J. Physiol. Gastrointest. Liver Physiol. 2013, 304, G1013-G1024. [CrossRef]

122. Cao, W.; Tian, W.; Hong, J.; Li, D.; Tavares, R.; Noble, L.; Moss, S.F.; Resnick, M.B. Expression of bile acid receptor TGR5 in gastric adenocarcinoma. Am. J. Physiol. Gastrointest. Liver Physiol. 2013, 304, G322-G327. [CrossRef]

123. Pathak, P.; Liu, H.; Boehme, S.; Xie, C.; Krausz, K.W.; Gonzalez, F.; Chiang, J.Y.L. Farnesoid X receptor induces Takeda G-protein receptor 5 cross-talk to regulate bile acid synthesis and hepatic metabolism. J. Biol. Chem. 2017, 292, 11055-11069. [CrossRef]

124. Mahajan-Thakur, S.; Bien-Moller, S.; Marx, S.; Schroeder, H.; Rauch, B.H. Sphingosine 1-phosphate (S1P) signaling in glioblastoma multiforme-A systematic review. Int. J. Mol. Sci. 2017, 18, 2448. [CrossRef]

125. Studer, E.; Zhou, X.; Zhao, R.; Wang, Y.; Takabe, K.; Nagahashi, M.; Pandak, W.M.; Dent, P.; Spiegel, S.; Shi, R.; et al. Conjugated bile acids activate the sphingosine-1-phosphate receptor 2 in primary rodent hepatocytes. Hepatology 2012, 55, 267-276. [CrossRef]

126. McMillin, M.; Frampton, G.; Grant, S.; Khan, S.; Diocares, J.; Petrescu, A.; Wyatt, A.; Kain, J.; Jefferson, B.; DeMorrow, S. Bile Acid-Mediated Sphingosine-1-Phosphate Receptor 2 Signaling Promotes Neuroinflammation during Hepatic Encephalopathy in Mice. Front. Cell Neurosci. 2017, 11, 191. [CrossRef]

127. Zhao, S.; Gong, Z.; Du, X.; Tian, C.; Wang, L.; Zhou, J.; Xu, C.; Chen, Y.; Cai, W.; Wu, J. Deoxycholic Acid-Mediated Sphingosine-1-Phosphate Receptor 2 Signaling Exacerbates DSS-Induced Colitis through Promoting Cathepsin B Release. J. Immunol. Res. 2018, 2018, 2481418. [CrossRef]

128. Kruse, A.C.; Kobilka, B.K.; Gautam, D.; Sexton, P.M.; Christopoulos, A.; Wess, J. Muscarinic acetylcholine receptors: Novel opportunities for drug development. Nat. Rev. Drug Discov. 2014, 13, 549-560. [CrossRef]

129. Ibrahim, E.; Diakonov, I.; Arunthavarajah, D.; Swift, T.; Goodwin, M.; Mcllvride, S.; Nikolova, V.; Williamson, C.; Gorelik, J. Bile acids and their respective conjugates elicit different responses in neonatal cardiomyocytes: Role of Gi protein, muscarinic receptors and TGR5. Sci. Rep. 2018, 8, 7110. [CrossRef] 
130. Sheikh Abdul Kadir, S.H.; Miragoli, M.; Abu-Hayyeh, S.; Moshkov, A.V.; Xie, Q.; Keitel, V.; Nikolaev, V.O.; Williamson, C.; Gorelik, J. Bile acid-induced arrhythmia is mediated by muscarinic M2 receptors in neonatal rat cardiomyocytes. PLoS ONE 2010, 5, e9689. [CrossRef]

131. Farhana, L.; Nangia-Makker, P.; Arbit, E.; Shango, K.; Sarkar, S.; Mahmud, H.; Hadden, T.; Yu, Y.; Majumdar, A.P. Bile acid: A potential inducer of colon cancer stem cells. Stem Cell Res. Ther. 2016, 7, 181. [CrossRef]

132. Khurana, S.; Yamada, M.; Wess, J.; Kennedy, R.H.; Raufman, J.P. Deoxycholyltaurine-induced vasodilation of rodent aorta is nitric oxide- and muscarinic M(3) receptor-dependent. Eur. J. Pharmacol. 2005, 517, 103-110. [CrossRef]

133. Schepetkin, I.A.; Khlebnikov, A.I.; Kirpotina, L.N.; Quinn, M.T. Antagonism of human formyl peptide receptor 1 with natural compounds and their synthetic derivatives. Int. Immunopharmacol. 2016, 37, 43-58. [CrossRef]

134. Chen, X.; Yang, D.; Shen, W.; Dong, H.F.; Wang, J.M.; Oppenheim, J.J.; Howard, M.Z. Characterization of chenodeoxycholic acid as an endogenous antagonist of the G-coupled formyl peptide receptors. Inflamm. Res. 2000, 49, 744-755. [CrossRef]

135. Chen, X.; Mellon, R.D.; Yang, L.; Dong, H.; Oppenheim, J.J.; Howard, O.M. Regulatory effects of deoxycholic acid, a component of the anti-inflammatory traditional Chinese medicine Niuhuang, on human leukocyte response to chemoattractants. Biochem. Pharmacol. 2002, 63, 533-541. [CrossRef]

136. Lenzig, P.; Wirtz, M.; Wiemuth, D. Comparative electrophysiological analysis of the bile acid-sensitive ion channel (BASIC) from different species suggests similar physiological functions. Pflugers Arch. 2019, 471, 329-336. [CrossRef]

137. Ilyaskin, A.V.; Diakov, A.; Korbmacher, C.; Haerteis, S. Activation of the Human Epithelial Sodium Channel (ENaC) by Bile Acids Involves the Degenerin Site. J. Biol. Chem. 2016, 291, 19835-19847. [CrossRef]

138. Dopico, A.M.; Walsh, J.V., Jr.; Singer, J.J. Natural bile acids and synthetic analogues modulate large conductance Ca2+-activated K+ (BKCa) channel activity in smooth muscle cells. J. Gen. Physiol. 2002, 119, 251-273. [CrossRef]

139. Bukiya, A.N.; Singh, A.K.; Parrill, A.L.; Dopico, A.M. The steroid interaction site in transmembrane domain 2 of the large conductance, voltage- and calcium-gated potassium (BK) channel accessory beta1 subunit. Proc. Natl. Acad. Sci. USA 2011, 108, 20207-20212. [CrossRef]

140. Abrams, P.; Andersson, K.E.; Buccafusco, J.J.; Chapple, C.; de Groat, W.C.; Fryer, A.D.; Kay, G.; Laties, A.; Nathanson, N.M.; Pasricha, P.J.; et al. Muscarinic receptors: Their distribution and function in body systems, and the implications for treating overactive bladder. Br. J. Pharmacol. 2006, 148, 565-578. [CrossRef]

141. Kiriyama, Y.; Nochi, H. D-Amino Acids in the Nervous and Endocrine Systems. Scientifica (Cairo) 2016, 2016, 6494621. [CrossRef]

142. Montes de Oca Balderas, P. Flux-Independent NMDAR Signaling: Molecular Mediators, Cellular Functions, and Complexities. Int. J. Mol. Sci. 2018, 19, 3800. [CrossRef]

143. Kumar, A. NMDA Receptor Function During Senescence: Implication on Cognitive Performance. Front. Neurosci. 2015, 9, 473. [CrossRef]

144. Cicek, S.S. Structure-Dependent Activity of Natural GABA(A) Receptor Modulators. Molecules 2018, $23,1512$. [CrossRef]

145. Schubring, S.R.; Fleischer, W.; Lin, J.S.; Haas, H.L.; Sergeeva, O.A. The bile steroid chenodeoxycholate is a potent antagonist at NMDA and GABA(A) receptors. Neurosci. Lett. 2012, 506, 322-326. [CrossRef]

146. Fujita, A.; Bonnavion, P.; Wilson, M.H.; Mickelsen, L.E.; Bloit, J.; de Lecea, L.; Jackson, A.C. Hypothalamic Tuberomammillary Nucleus Neurons: Electrophysiological Diversity and Essential Role in Arousal Stability. J. Neurosci. 2017, 37, 9574-9592. [CrossRef]

147. Xie, J.F.; Fan, K.; Wang, C.; Xie, P.; Hou, M.; Xin, L.; Cui, G.F.; Wang, L.X.; Shao, Y.F.; Hou, Y.P. Inactivation of the Tuberomammillary Nucleus by GABAA Receptor Agonist Promotes Slow Wave Sleep in Freely Moving Rats and Histamine-Treated Rats. Neurochem. Res. 2017, 42, 2314-2325. [CrossRef]

148. Yanovsky, Y.; Schubring, S.R.; Yao, Q.; Zhao, Y.; Li, S.; May, A.; Haas, H.L.; Lin, J.S.; Sergeeva, O.A. Waking action of ursodeoxycholic acid (UDCA) involves histamine and GABAA receptor block. PLoS ONE 2012, 7, e42512. [CrossRef] 
149. Soares, R.; Ribeiro, F.F.; Xapelli, S.; Genebra, T.; Ribeiro, M.F.; Sebastiao, A.M.; Rodrigues, C.M.P.; Sola, S. Tauroursodeoxycholic Acid Enhances Mitochondrial Biogenesis, Neural Stem Cell Pool, and Early Neurogenesis in Adult Rats. Mol. Neurobiol. 2018, 55, 3725-3738. [CrossRef]

150. Bond, A.M.; Ming, G.L.; Song, H. Adult Mammalian Neural Stem Cells and Neurogenesis: Five Decades Later. Cell Stem Cell 2015, 17, 385-395. [CrossRef]

151. Holtzman, D.M.; Morris, J.C.; Goate, A.M. Alzheimer's disease: The challenge of the second century. Sci. Transl. Med. 2011, 3, 77sr71. [CrossRef]

152. Cole, S.L.; Vassar, R. The Basic Biology of BACE1: A Key Therapeutic Target for Alzheimer's Disease. Curr. Genom. 2007, 8, 509-530.

153. Tomita, T. Molecular mechanism of intramembrane proteolysis by gamma-secretase. J. Biochem. 2014, 156, 195-201. [CrossRef]

154. Sun, L.; Zhao, L.; Yang, G.; Yan, C.; Zhou, R.; Zhou, X.; Xie, T.; Zhao, Y.; Wu, S.; Li, X.; et al. Structural basis of human gamma-secretase assembly. Proc. Natl. Acad. Sci. USA 2015, 112, 6003-6008. [CrossRef]

155. Lee, J.H.; Yu, W.H.; Kumar, A.; Lee, S.; Mohan, P.S.; Peterhoff, C.M.; Wolfe, D.M.; Martinez-Vicente, M.; Massey, A.C.; Sovak, G.; et al. Lysosomal proteolysis and autophagy require presenilin 1 and are disrupted by Alzheimer-related PS1 mutations. Cell 2010, 141, 1146-1158. [CrossRef]

156. Nunes, A.F.; Amaral, J.D.; Lo, A.C.; Fonseca, M.B.; Viana, R.J.; Callaerts-Vegh, Z.; D’Hooge, R.; Rodrigues, C.M. TUDCA, a bile acid, attenuates amyloid precursor protein processing and amyloid-beta deposition in APP/PS1 mice. Mol. Neurobiol. 2012, 45, 440-454. [CrossRef]

157. Lo, A.C.; Callaerts-Vegh, Z.; Nunes, A.F.; Rodrigues, C.M.; D’Hooge, R. Tauroursodeoxycholic acid (TUDCA) supplementation prevents cognitive impairment and amyloid deposition in APP/PS1 mice. Neurobiol. Dis. 2013, 50, 21-29. [CrossRef]

158. Marksteiner, J.; Blasko, I.; Kemmler, G.; Koal, T.; Humpel, C. Bile acid quantification of 20 plasma metabolites identifies lithocholic acid as a putative biomarker in Alzheimer's disease. Metabolomics 2018, 14, 1. [CrossRef]

159. MahmoudianDehkordi, S.; Arnold, M.; Nho, K.; Ahmad, S.; Jia, W.; Xie, G.; Louie, G.; Kueider-Paisley, A.; Moseley, M.A.; Thompson, J.W.; et al. Altered bile acid profile associates with cognitive impairment in Alzheimer's disease-An emerging role for gut microbiome. Alzheimers Dement. 2019, 15, 76-92. [CrossRef]

160. Area-Gomez, E.; de Groof, A.; Bonilla, E.; Montesinos, J.; Tanji, K.; Boldogh, I.; Pon, L.; Schon, E.A. A key role for MAM in mediating mitochondrial dysfunction in Alzheimer disease. Cell Death Dis. 2018, 9, 335. [CrossRef]

161. Gao, J.; Wang, L.; Liu, J.; Xie, F.; Su, B.; Wang, X. Abnormalities of Mitochondrial Dynamics in Neurodegenerative Diseases. Antioxidants (Basel) 2017, 6, 25. [CrossRef]

162. Kiriyama, Y.; Nochi, H. Intra- and Intercellular Quality Control Mechanisms of Mitochondria. Cells $2018,7,1$. [CrossRef]

163. Bell, S.M.; Barnes, K.; Clemmens, H.; Al-Rafiah, A.R.; Al-Ofi, E.A.; Leech, V.; Bandmann, O.; Shaw, P.J.; Blackburn, D.J.; Ferraiuolo, L.; et al. Ursodeoxycholic Acid Improves Mitochondrial Function and Redistributes Drp1 in Fibroblasts from Patients with Either Sporadic or Familial Alzheimer's Disease. J. Mol. Biol 2018, 430, 3942-3953. [CrossRef]

164. Jankovic, J. Parkinson's disease: Clinical features and diagnosis. J. Neurol. Neurosurg. Psychiatry 2008, 79, 368-376. [CrossRef]

165. Kiriyama, Y.; Nochi, H. The Function of Autophagy in Neurodegenerative Diseases. Int. J. Mol. Sci. 2015, 16, 26797-26812. [CrossRef]

166. Gladkova, C.; Maslen, S.L.; Skehel, J.M.; Komander, D. Mechanism of parkin activation by PINK1. Nature 2018, 559, 410-414. [CrossRef]

167. Hardy, J. Genetic analysis of pathways to Parkinson disease. Neuron 2010, 68, 201-206. [CrossRef]

168. Pickrell, A.M.; Youle, R.J. The roles of PINK1, parkin, and mitochondrial fidelity in Parkinson's disease. Neuron 2015, 85, 257-273. [CrossRef]

169. Heo, J.M.; Ordureau, A.; Paulo, J.A.; Rinehart, J.; Harper, J.W. The PINK1-PARKIN Mitochondrial Ubiquitylation Pathway Drives a Program of OPTN/NDP52 Recruitment and TBK1 Activation to Promote Mitophagy. Mol. Cell 2015, 60, 7-20. [CrossRef]

170. Lazarou, M.; Sliter, D.A.; Kane, L.A.; Sarraf, S.A.; Wang, C.; Burman, J.L.; Sideris, D.P.; Fogel, A.I.; Youle, R.J. The ubiquitin kinase PINK1 recruits autophagy receptors to induce mitophagy. Nature 2015, 524, 309-314. [CrossRef] 
171. Martinez, T.N.; Greenamyre, J.T. Toxin models of mitochondrial dysfunction in Parkinson's disease. Antioxid. Redox Signal. 2012, 16, 920-934. [CrossRef]

172. Connolly, N.M.C.; Theurey, P.; Adam-Vizi, V.; Bazan, N.G.; Bernardi, P.; Bolanos, J.P.; Culmsee, C.; Dawson, V.L.; Deshmukh, M.; Duchen, M.R.; et al. Guidelines on experimental methods to assess mitochondrial dysfunction in cellular models of neurodegenerative diseases. Cell Death Differ. 2018, 25, 542-572. [CrossRef]

173. Castro-Caldas, M.; Carvalho, A.N.; Rodrigues, E.; Henderson, C.J.; Wolf, C.R.; Rodrigues, C.M.; Gama, M.J. Tauroursodeoxycholic acid prevents MPTP-induced dopaminergic cell death in a mouse model of Parkinson's disease. Mol. Neurobiol. 2012, 46, 475-486. [CrossRef]

174. Moreira, S.; Fonseca, I.; Nunes, M.J.; Rosa, A.; Lemos, L.; Rodrigues, E.; Carvalho, A.N.; Outeiro, T.F.; Rodrigues, C.M.P.; Gama, M.J.; et al. Nrf2 activation by tauroursodeoxycholic acid in experimental models of Parkinson's disease. Exp. Neurol. 2017, 295, 77-87. [CrossRef]

175. Rosa, A.I.; Duarte-Silva, S.; Silva-Fernandes, A.; Nunes, M.J.; Carvalho, A.N.; Rodrigues, E.; Gama, M.J.; Rodrigues, C.M.P.; Maciel, P.; Castro-Caldas, M. Tauroursodeoxycholic Acid Improves Motor Symptoms in a Mouse Model of Parkinson's Disease. Mol. Neurobiol. 2018, 55, 9139-9155. [CrossRef]

176. Rosa, A.I.; Fonseca, I.; Nunes, M.J.; Moreira, S.; Rodrigues, E.; Carvalho, A.N.; Rodrigues, C.M.P.; Gama, M.J.; Castro-Caldas, M. Novel insights into the antioxidant role of tauroursodeoxycholic acid in experimental models of Parkinson's disease. Biochim. Biophys. Acta Mol. Basis Dis. 2017, 1863, 2171-2181. [CrossRef]

177. Abdelkader, N.F.; Safar, M.M.; Salem, H.A. Ursodeoxycholic Acid Ameliorates Apoptotic Cascade in the Rotenone Model of Parkinson's Disease: Modulation of Mitochondrial Perturbations. Mol. Neurobiol. 2016, 53, 810-817. [CrossRef]

178. Dayalu, P.; Albin, R.L. Huntington disease: Pathogenesis and treatment. Neurol. Clin. 2015, 33, 101-114. [CrossRef]

179. The Huntington's Disease Collaborative Research Group. A novel gene containing a trinucleotide repeat that is expanded and unstable on Huntington's disease chromosomes. Cell 1993, 72, 971-983.

180. Tunez, I.; Tasset, I.; Perez-De La Cruz, V.; Santamaria, A. 3-Nitropropionic acid as a tool to study the mechanisms involved in Huntington's disease: Past, present and future. Molecules 2010, 15, 878-916. [CrossRef]

181. Li, J.Y.; Popovic, N.; Brundin, P. The use of the R6 transgenic mouse models of Huntington's disease in attempts to develop novel therapeutic strategies. NeuroRx 2005, 2, 447-464. [CrossRef]

182. Keene, C.D.; Rodrigues, C.M.; Eich, T.; Linehan-Stieers, C.; Abt, A.; Kren, B.T.; Steer, C.J.; Low, W.C. A bile acid protects against motor and cognitive deficits and reduces striatal degeneration in the 3-nitropropionic acid model of Huntington's disease. Exp. Neurol. 2001, 171, 351-360. [CrossRef]

183. Mangiarini, L.; Sathasivam, K.; Seller, M.; Cozens, B.; Harper, A.; Hetherington, C.; Lawton, M.; Trottier, Y.; Lehrach, H.; Davies, S.W.; et al. Exon 1 of the HD gene with an expanded CAG repeat is sufficient to cause a progressive neurological phenotype in transgenic mice. Cell 1996, 87, 493-506. [CrossRef]

184. Keene, C.D.; Rodrigues, C.M.; Eich, T.; Chhabra, M.S.; Steer, C.J.; Low, W.C. Tauroursodeoxycholic acid, a bile acid, is neuroprotective in a transgenic animal model of Huntington's disease. Proc. Natl. Acad. Sci. USA 2002, 99, 10671-10676. [CrossRef]

185. Juenemann, K.; Jansen, A.H.P.; van Riel, L.; Merkx, R.; Mulder, M.P.C.; An, H.; Statsyuk, A.; Kirstein, J.; Ovaa, H.; Reits, E.A. Dynamic recruitment of ubiquitin to mutant huntingtin inclusion bodies. Sci. Rep. 2018, 8, 1405. [CrossRef]

186. Mancuso, R.; Navarro, X. Amyotrophic lateral sclerosis: Current perspectives from basic research to the clinic. Prog. Neurobiol. 2015, 133, 1-26. [CrossRef]

187. Renton, A.E.; Chio, A.; Traynor, B.J. State of play in amyotrophic lateral sclerosis genetics. Nat. Neurosci. 2014, 17, 17-23. [CrossRef]

188. De Giorgio, F.; Maduro, C.; Fisher, E.M.C.; Acevedo-Arozena, A. Transgenic and physiological mouse models give insights into different aspects of amyotrophic lateral sclerosis. Dis. Model. Mech 2019, 12. [CrossRef]

189. Muyderman, H.; Hutson, P.G.; Matusica, D.; Rogers, M.L.; Rush, R.A. The human G93A-superoxide dismutase-1 mutation, mitochondrial glutathione and apoptotic cell death. Neurochem. Res. 2009, 34, 1847-1856. [CrossRef] 
190. Vaz, A.R.; Cunha, C.; Gomes, C.; Schmucki, N.; Barbosa, M.; Brites, D. Glycoursodeoxycholic acid reduces matrix metalloproteinase- 9 and caspase- 9 activation in a cellular model of superoxide dismutase-1 neurodegeneration. Mol. Neurobiol. 2015, 51, 864-877. [CrossRef]

191. Elia, A.E.; Lalli, S.; Monsurro, M.R.; Sagnelli, A.; Taiello, A.C.; Reggiori, B.; La Bella, V.; Tedeschi, G.; Albanese, A. Tauroursodeoxycholic acid in the treatment of patients with amyotrophic lateral sclerosis. Eur. J. Neurol. 2016, 23, 45-52. [CrossRef]

192. Sarenac, T.M.; Mikov, M. Bile Acid Synthesis: From Nature to the Chemical Modification and Synthesis and Their Applications as Drugs and Nutrients. Front. Pharmacol. 2018, 9, 939. [CrossRef]

193. Parry, G.J.; Rodrigues, C.M.; Aranha, M.M.; Hilbert, S.J.; Davey, C.; Kelkar, P.; Low, W.C.; Steer, C.J. Safety, tolerability, and cerebrospinal fluid penetration of ursodeoxycholic Acid in patients with amyotrophic lateral sclerosis. Clin. Neuropharmacol. 2010, 33, 17-21. [CrossRef]

(C) 2019 by the authors. Licensee MDPI, Basel, Switzerland. This article is an open access article distributed under the terms and conditions of the Creative Commons Attribution (CC BY) license (http://creativecommons.org/licenses/by/4.0/). 